\title{
Stable Complexes Involving Acetylcholinesterase and Amyloid- $\beta$ Peptide Change the Biochemical Properties of the Enzyme and Increase the Neurotoxicity of Alzheimer's Fibrils
}

\author{
Alejandra Alvarez, ${ }^{1}$ Rodrigo Alarcón, ${ }^{1}$ Carlos Opazo, ${ }^{1}$ Eliseo O. Campos, ${ }^{1}$ Francisco José Muñoz, ${ }^{1}$ \\ Frances H. Calderón, ${ }^{1}$ Federico Dajas, ${ }^{2}$ Mary K. Gentry, ${ }^{3}$ Bhupendra P. Doctor, ${ }^{3}$ Fernando G. De Mello, ${ }^{4}$ and \\ Nibaldo C. Inestrosa ${ }^{1}$ \\ ${ }^{1}$ Departamento de Biología Celular y Molecular, Facultad de Ciencias Biológicas, Pontificia Universidad Católica de Chile, \\ Santiago, Chile, 2División de Neuroquímica, Instituto de Investigaciones Biológicas Clemente Estable, Montevideo, \\ Uruguay, "3Division of Biochemistry, Walter Reed Army Institute of Research, Washington, DC, 20307-5100, and 4/nstituto \\ de Biofisica, Universidade Federal do Rio de Janeiro, Rio de Janeiro, Brazil
}

Brain acetylcholinesterase (AChE) forms stable complexes with amyloid- $\beta$ peptide $(\mathrm{A} \beta)$ during its assembly into filaments, in agreement with its colocalization with the $A \beta$ deposits of Alzheimer's brain. The association of the enzyme with nascent $A \beta$ aggregates occurs as early as after $30 \mathrm{~min}$ of incubation. Analysis of the catalytic activity of the AChE incorporated into these complexes shows an anomalous behavior reminiscent of the AChE associated with senile plaques, which includes a resistance to low $\mathrm{pH}$, high substrate concentrations, and lower sensitivity to AChE inhibitors. Furthermore, the toxicity of the
AChE-amyloid complexes is higher than that of the $\mathrm{A} \beta$ aggregates alone. Thus, in addition to its possible role as a heterogeneous nucleator during amyloid formation, AChE, by forming such stable complexes, may increase the neurotoxicity of $A \beta$ fibrils and thus may determine the selective neuronal loss observed in Alzheimer's brain.

Key words: AChE; $A \beta$-amyloid fibrils; $A C h E-A \beta$-amyloid fibril complexes; amyloid formation; Alzheimer's disease; neurotoxicity
Alzheimer's disease (AD), the most common form of dementia in adults, is a neurodegenerative disorder characterized by selective neuronal loss and the presence of two different types of fibril deposits: amyloid plaques and neurofibrillary tangles (Soto et al., 1994; Selkoe, 1996). Recent advances in the molecular genetics of AD indicate that it is a complex disorder with mutations in many genes, and the apolipoprotein E genotype is a risk factor (Selkoe, 1997). However, at least $60 \%$ of AD patients do not have a family history of the disease. Therefore, there is a need to search for the mechanisms responsible for the progressive cognitive decline observed in most of the sporadic cases, which correspond to the great majority of Alzheimer's patients (Katzman and Kawas, 1994; Inestrosa et al., 1996a; Van Leeuwen et al., 1998). The fact that neurodegenerative changes occur around senile plaques (Mann and Esiri, 1989), and that the neurotoxicity of $\mathrm{A} \beta$ depends on its aggregation into amyloid fibrils (Lorenzo and Yankner, 1994), indicates that amyloid fibrils are the primary pathogenic mechanism in AD (Yankner, 1996). It has also been suggested that endogenous factors that modulate $\mathrm{A} \beta$ fibrillogenesis and deposition could play a significant role in the pathogenesis of the disease (Inestrosa et al., 1996b; Harper and Lansbury, 1997). In

\footnotetext{
Received Dec. 3, 1997; revised Feb. 12, 1998; accepted Feb. 17, 1998.

This research was supported by Fondo Nacional de Desarrollo Científico y Technológico Grant 1971240 to N.C.I., Comisión Nacional de Investigación Científica y Technológica PhD Thesis Award 2960052 to A.A., and a predoctoral fellowship from Dirección de Investigación y Postgrado, Pontificia Universidad Católica de Chile to C.O. N.C.I. is a recipient of a Presidential Chair in Science from the Chilean Government. F.J.M. is on leave from Hospital La Princesa (Madrid, Spain).

Correspondence should be addressed to Dr. Nibaldo C. Inestrosa, Molecular Neurobiology Unit, Catholic University of Chile, P.O. Box 114-D, Santiago, Chile. Copyright (C) 1998 Society for Neuroscience $0270-6474 / 98 / 183213-11 \$ 05.00 / 0$
}

this context, several studies have revealed numerous other proteins associated with the amyloid plaque deposits. These proteins include apolipoprotein E (apoE) (Namba et al., 1991), $\alpha_{1}$-anti-chymotrypsin (Abraham et al., 1988), heparan sulfate proteoglycans (Snow et al., 1988), and acetylcholinesterase (AChE) (Ulrich et al., 1990). AChE plays a key role in cholinergic transmission in the CNS of mammals (Inestrosa and Perelman, 1989, 1990; Taylor, 1991) and may also participate in noncholinergic mechanisms (Massoulié et al., 1993; Small et al., 1996). Most of the cortical AChE activity present in Alzheimer's brain is predominantly associated with the amyloid core of senile plaques rather than with the neuritic component found at the periphery (Ulrich et al., 1990; Gómez-Ramos et al., 1992; Morán et al., 1993). Histochemical studies have demonstrated that the AChE associated with senile plaques differs enzymatically from the AChE associated with normal fibers and neurons with respect to optimum $\mathrm{pH}$, inhibitor sensitivity, and inhibition by excess substrate (Mesulam et al., 1987; Geula and Mesulam, 1989; Schätz et al., 1990; Wright et al., 1993). AChE directly promotes the assembly of $\mathrm{A} \beta$ peptide into amyloid fibrils (Alvarez et al., 1995; Inestrosa et al., 1996b), and recent studies from our laboratory have shown that $\mathrm{AChE}$ forms complexes with small $\mathrm{A} \beta$ peptide fragments (Alvarez et al., 1997). It was therefore our aim to investigate whether the characteristics of AChE observed in the amyloid plaques of Alzheimer's brain could be reproduced under in vitro conditions, using complexes obtained with whole $\mathrm{A} \beta_{1-40}$ peptide. We report here that the incorporation of $\mathrm{AChE}$ into Alzheimer's amyloid aggregates results in the formation of stable complexes that change the biochemical and pharmacological properties of the enzyme and cause an increase in the neurotoxicity of the amyloid- $\beta$ fibrils, suggesting that AChE could play a 
pathogenic role in $\mathrm{AD}$ by influencing the process leading to amyloid toxicity and the appearance of AD.

\section{MATERIALS AND METHODS}

Materials. Synthetic peptide $\mathrm{A} \beta_{1-40}$, corresponding to residues 1-40 of the human $A \beta$ sequence, was purchased from Chiron Corporation (Emeryville CA). The following inhibitors were purchased from Sigma (St. Louis, MO): edrophonium chloride, tetrahydro-aminoacridine hydrochloride (Tacrine), and propidium iodide. Fasciculin was purified as described previously (Dajas et al., 1987; Karlsson et al., 1984), and the monoclonal antibody 25B1 directed against fetal bovine serum AChE was obtained as described by Gentry et al. (1995).

Purification of brain AChE. The tetrameric $\mathrm{G}_{4}$ AChE form (sedimentation coefficient, $10.7 \mathrm{~S}$ ) was purified from bovine caudate nucleus, using acridine affinity chromatography, as described previously (Inestrosa et al., 1987). Both specific activities (6000 U/mg protein), and staining intensities after SDS-PAGE (Laemmli, 1970) (a single band of $66 \mathrm{kDa}$ ) were used to verify purity.

AChE assay. AChE activity was determined by the method of Ellman et al. (1961).

Preparation of ${ }^{125} I-T y r$ derivatives of $A C h E$ and $A \beta_{1-40}$. For the iodination of $\mathrm{AChE}$ and the $\mathrm{A} \beta$ peptide, the iodo-bead method was used (Markwell, 1982); $100 \mu \mathrm{g}$ of AChE was labeled with $500 \mu \mathrm{Ci}^{125} \mathrm{I}-\mathrm{Na}$, and $100 \mu \mathrm{g}$ of $\mathrm{A} \beta_{1-40}$ peptide was labeled with $1000 \mu \mathrm{Ci}{ }^{125} \mathrm{I}-\mathrm{Na}$ (Comisión de Energía Nuclear de Chile). A single bead was used in each case and incubated in $200 \mu \mathrm{l}$ of $0.1 \mathrm{M}$ phosphate buffer, $\mathrm{pH} 7.0$, for $15 \mathrm{~min}$. The iodinated enzyme was separated from the unreacted ${ }^{125} \mathrm{I}$ on a Sephadex G-25 column and submitted to $12 \%$ SDS-PAGE (Laemmli, 1970). Autoradiography showed a main band (at $66 \mathrm{kDa}$ ) coincident with the electrophoretic migration of native AChE. The specific activity of the standard ${ }^{125} \mathrm{I}-\mathrm{AChE}$ used in our experiments was estimated on the order of $2.4 \mathrm{mCi} / \mathrm{mmol}$. For the iodinated $\mathrm{A} \beta$ peptide, a Sepharose Bio-Gel P-2 column was used to separate the peptide from free ${ }^{125} \mathrm{I}$, and the labeled peptide fraction was submitted to Tris-Tricine 16\% SDS-PAGE (Schagger and von Jagow, 1987). Autoradiography showed a single band (at 4 $\mathrm{kDa}$ ) coincident with the electrophoretic pattern of the native $\mathrm{A} \beta_{1-40}$ peptide. The specific activity of the standard ${ }^{125} \mathrm{I}-\mathrm{A} \beta$ peptide used in our experiments was estimated on the order of $0.6 \mathrm{mCi} / \mathrm{mmol}$, and the peptide was used immediately after radioiodination.

Generation of $A C h E-A \beta$ complexes in vitro. To obtain $\mathrm{AChE}-\mathrm{A} \beta$ complexes, $\mathrm{A} \beta_{1-40}$ peptide was incubated with or without AChE in a stirred aggregation assay performed as described previously (Jarrett et al., 1993; Evans et al., 1995). Briefly, stock solutions were prepared by dissolving lyophilized aliquots of the $\mathrm{A} \beta$ peptide in dimethyl sulfoxide (DMSO) at $15 \mathrm{mg} / \mathrm{ml}(3.5 \mathrm{~mm})$. Aliquots of peptide stock solution (70 nmol in $\simeq 20 \mu$ l of DMSO) were added to PBS, $\mathrm{pH} 7.4$, for a final volume of $725 \mu \mathrm{l}$. For the aggregation experiments performed with AChE, peptide stock (70 nmol in DMSO) was added to $680 \mu \mathrm{l}$ of PBS buffer containing AChE $(100 \mathrm{nM} ; 25 \mu \mathrm{g}$ of the enzyme in $\sim 25 \mu \mathrm{l}$ of buffer: 20 mM sodium phosphate, $1 \mathrm{~mm}$ EDTA, $0.1 \%$ Triton X-100, and $10 \mathrm{~mm}$ caproic acid, $\mathrm{pH}$ 7.4). The solutions were stirred continuously (210 rpm), and aggregation was measured versus buffer blank by turbidity at $405 \mathrm{~nm}$. After $6 \mathrm{hr}$ of incubation with stirring, the mixtures were incubated without stirring for 4-5 d after which the aggregates formed were analyzed.

Congo red (CR) assay. CR binding to amyloid aggregates was used as described previously (Klunk et al., 1989). Aliquots $(40 \mu \mathrm{l})$ of the aggregation mixtures were added to $960 \mu \mathrm{l}$ of a solution of $25 \mu \mathrm{M} \mathrm{CR}, 100 \mathrm{mM}$ phosphate buffer, $\mathrm{pH} 7.4$, and $150 \mathrm{~mm} \mathrm{NaCl}$ and incubated for $30 \mathrm{~min}$. Absorbance was measured at 480 and $540 \mathrm{~nm}$. The CR binding was estimated by $\mathrm{CR}(\mathrm{M})=\left(A^{540} / 25,295\right)-\left(A^{480} / 46,306\right)$.

$A C h E$ activity in amyloid fibrils. Four hundred-microliter aliquots of the $\mathrm{A} \beta_{1-40}$ fibrils formed in the presence of $\mathrm{AChE}$ in aggregation assays (5 $\mathrm{d}$ of incubation) were centrifuged at $14,000 \mathrm{rpm}$ for $30 \mathrm{~min}$. The supernatants were removed, and the $\mathrm{AChE}-\mathrm{A} \beta$ complexes were resuspended in $400 \mu \mathrm{l}$ of PBS. To remove noncomplexed AChE, the aggregates were washed three times by centrifugation, and resuspension in $400 \mu \mathrm{l}$ of PBS was accomplished by vortex stirring. The final pellet was resuspended in $100 \mu \mathrm{l}$ of PBS. To quantify the fraction of AChE present in the $\mathrm{AChE}-\mathrm{A} \beta$ complexes, the enzymatic activity in the final pellet and supernatants was determined by the assay of Ellman et al. (1961). In addition, ${ }^{125} \mathrm{I}-\mathrm{AChE}$ was used to form $\mathrm{AChE}-\mathrm{A} \beta$ complexes, and the radioactivity in the same fractions was also quantified. Furthermore, AChE activity associated with the amyloid fibrils in vitro was detected by histochemical staining of the washed aggregates (Karnovsky and Roots,
1964). The amyloid character of the $A \beta_{1-40}$ fibrils was evidenced by the binding of thioflavine-T (LeVine, 1993) and detected under a fluorescence microscope, as described previously (Alvarez et al., 1997). Control samples in which $\mathrm{A} \beta$ was incubated alone were subjected to the same procedures.

Dissociation studies of the AChE-A $\beta$ complexes. A $10 \mu \mathrm{l}$ aliquot of the ${ }^{125} \mathrm{I}-\mathrm{AChE}-\mathrm{A} \beta$ complexes (final pellet) was added to $290 \mu \mathrm{l}$ of each of the agents listed below. The complexes were incubated in polypropylene tubes with each agent for $1 \mathrm{hr}$ with gentle stirring. The aggregates were then centrifuged at $14,000 \mathrm{rpm}$ for $30 \mathrm{~min}$, and both the AChE activity and radioactivity present in the pellet and the supernatant were determined. The agents used were $1 \%$ SDS, $6 \mathrm{~m}$ guanidine-HCl, $6 \mathrm{~m}$ guanidine isothiocyanate, $8 \mathrm{M}$ urea, PBS-1\% Tween 20, PBS-1\% Triton X-100, $1 \mathrm{M}$ $\mathrm{NaCl}$, and $2 \mathrm{M} \mathrm{MgCl}_{2}$.

Velocity sedimentation analysis. $\mathrm{AChE}\left(\mathrm{G}_{4}\right.$ form $)$ alone or the $\mathrm{AChE}-$ ${ }^{125} \mathrm{I}-\mathrm{A} \beta$ complexes produced in the stirred kinetic assays were submitted to velocity sedimentation analysis in 5-20\% sucrose gradients, containing a $70 \%$ sucrose cushion at the bottom of the centrifuge tube. A CombiSorvall ultracentrifuge was used. Fractions were collected from the bottom of the gradient as described previously (Inestrosa et al., 1996b).

Immunogold labeling of the $A C h E-A \beta$ complexes. For immunogold staining, AChE-A $\beta$ complexes were adsorbed onto nickel grids covered by a carbon-stabilized Formvar film and air-dried. After washing in buffer (0.05 M Tris-HCl, $\mathrm{pH} 7.4)$ for $2 \mathrm{~min}$, nonspecific binding was blocked by incubation in $0.05 \mathrm{M}$ Tris- $\mathrm{HCl}, \mathrm{pH} 7.4$, with $1 \%$ ovalbumin for $1 \mathrm{hr}$. The grids were then placed on a droplet of anti-AChE polyclonal antibody diluted $1: 50$ in $0.05 \mathrm{M}$ Tris- $\mathrm{HCl}, \mathrm{pH} 7.4$, with $1 \%$ ovalbumin and incubated at $4^{\circ} \mathrm{C}$ overnight. These were passed under five droplets of washing solution $(0.05 \mathrm{M}$ Tris-HCl, $\mathrm{pH} 7.4$, with $0.05 \%$ Tween 20$)$ for 5 min each time, placed on a droplet of anti-rabbit IgG conjugated to 10 $\mathrm{nm}$ colloidal gold particles for $1 \mathrm{hr}$ (Sigma; diluted 1:20 in $0.05 \mathrm{M}$ Tris-HCl, pH 7.4, with $1 \%$ ovalbumin), and passed under another five droplets of washing solution (Naslund et al., 1995). Before the final examination under a JEOL 100-B electron microscope, the specimens were negatively stained with $2 \%$ uranyl acetate in water.

Determination of kinetic parameters. The kinetics of AChE activity were determined using appropriate dilutions of acetylthiocholine in the activity assay; the concentrations used were in the range of $0.03-1.0 \mathrm{mM}$, and separate blanks were used for each substrate concentration. The reaction was started by the addition of enzyme or AChE-A $\beta$ complex. The $K_{\mathrm{m}}$ and $V_{\max }$ values for acetylthiocholine were calculated by regression analysis of the linear portions of the Lineweaver-Burk plots (1/V vs $1 / S)$. The substrate inhibition constants $\left(K_{\mathrm{ss}}\right)$ were determined from a plot of $1 / V$ versus $[S]$ for $[S]>1.0 \mathrm{~mm}$ (Radic et al., 1991).

Inhibition of AChE activity. The $\mathrm{IC}_{50}$ values for edrophonium, Tacrine, and propidium (where $\mathrm{IC}_{50}$ is the inhibitor concentration required for $50 \%$ inhibition of AChE activity) were determined by incubating AChE and $\mathrm{AChE}-\mathrm{A} \beta$ complexes with varying concentrations of each inhibitor. The reaction was started by the addition of the substrate mixture, with the acetylthiocholine concentration fixed at $0.75 \mathrm{~mm}$, and incubated for $30 \mathrm{~min}$ at $37^{\circ} \mathrm{C}$. $\mathrm{IC}_{50}$ values were calculated by logarithmic plot analysis. Inhibition coefficient values $\left(K_{\mathrm{i}}\right)$ were calculated from the equation $K_{\mathrm{i}}=$ $\mathrm{IC}_{50} / 1+\left(S / K_{\mathrm{m}}\right)$, as described by Hobbiger and Peck (1969) where $S$ represents the concentration of acetylthiocholine $(0.75 \mathrm{~mm})$, and $\mathrm{K}_{\mathrm{m}}$ represents the Michaelis-Menten constant.

pH dependence. To study the $\mathrm{pH}$ dependence of the enzymatic activity of $\mathrm{AChE}$ and the AChE-A $\beta$ complexes, activity assays were performed at different $\mathrm{pH}$ values. The optimal $\mathrm{pH}$ was determined over a range of 4.0-9.0 in PBS buffer. $\mathrm{pH}$ values were measured with a $\mathrm{pH}$ meter standardized at $25^{\circ} \mathrm{C}$ to $\pm 0.01 \mathrm{pH}$ unit. The buffer was titrated to the required $\mathrm{pH}$ by the addition of $\mathrm{HCl}$ for $\mathrm{pH}$ values $<5.0$ and by $\mathrm{NaOH}$ for $\mathrm{pH}$ values $>8.0$.

Cytotoxicity assays in PC12 cells. Rat pheochromocytoma (PC12) cells (Greene and Tischler, 1976; Inestrosa et al., 1981) were cultured in DMEM, $10 \%$ fetal calf serum (FCS), $5 \%$ horse serum, $100 \mathrm{U} / \mathrm{ml}$ penicillin/streptomycin, and $2 \mathrm{~mm}$ L-Gln. For the cytotoxicity assays, cells were seeded in 96-well plates in serum-free medium with $2 \mu \mathrm{M}$ insulin at a density of $4 \times 10^{3}$ cells/100 $\mu$ l per well (Solomon et al., 1997). $\mathrm{AChE}-\mathrm{A} \beta$ complexes, amyloid fibrils, or PBS (control) were added to the wells at different concentrations in a final volume of $10 \mu$ l. The cells were incubated for $48 \mathrm{hr}$ at $37^{\circ} \mathrm{C}$, after which cell viability was measured by the 3-(4,5-dimethylthiazol-2-yl)-2,5-diphenyltetrazolium bromide (MTT) method (Mosmann, 1983). This involves determining the mitochondrial dehydrogenase activity in intact cells by incubating for $4 \mathrm{hr}$ at $37^{\circ} \mathrm{C}$ with $1 \mathrm{mg} / \mathrm{ml} \mathrm{MTT}$. The reaction was stopped by the addition of cell 


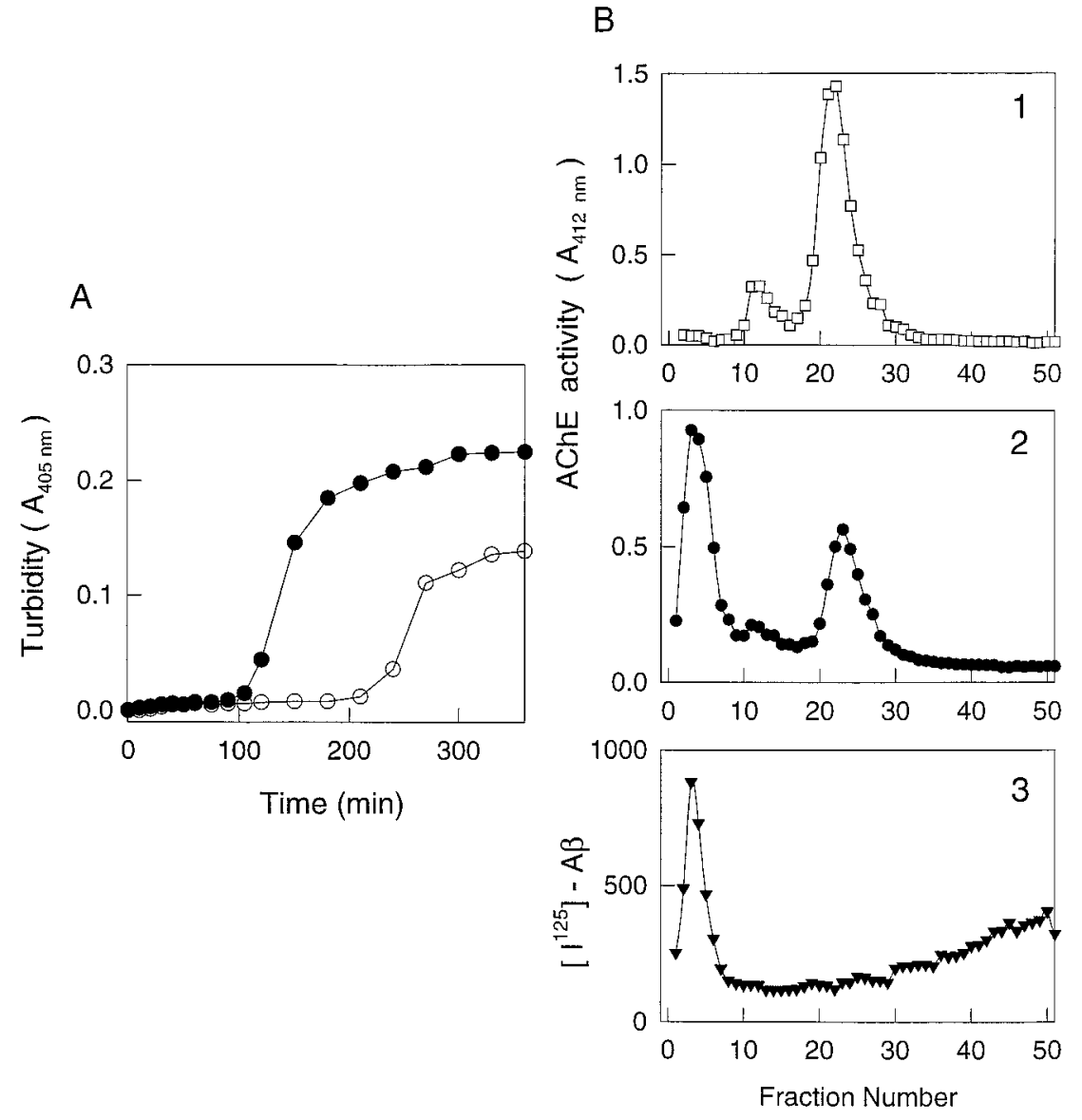

Figure 1. The AChE is associated with $\mathrm{A} \beta$ amyloid fibrils. $A, \mathrm{~A} \beta$ peptide aggregation assay. $\mathrm{A} \beta$ peptide $(97$ $\mu \mathrm{M}$ in PBS, $\mathrm{pH}$ 7.4) was incubated in a kinetic stirred assay, with $(\bullet)$ or without $(\bigcirc) \operatorname{AChE}(0.1 \mu \mathrm{M})$. A $\beta$ aggregation was followed by turbidity at $405 \mathrm{~nm}$. $B$, Sedimentation velocity analysis. Native brain AChE $(10.7 \mathrm{~S})$ as control and ${ }^{125} \mathrm{I}-\mathrm{A} \beta$ amyloid aggregates produced in a stirred kinetic assay with AChE were submitted to velocity sedimentation analysis in 5-20\% sucrose gradients containing a $70 \%$ sucrose cushion at the bottom of the centrifuge tube. A Combi-Sorval ultracentrif uge was used. Fractions were collected from the bottom of the gradient as described previously (Inestrosa et al., 1994). AChE activity and radioactivity in the corresponding fractions were determined. 1 , Control $\mathrm{G}_{4}$ AChE; 2 , AChE-A $\beta$ aggregates; $3,{ }^{125} \mathrm{I}-\mathrm{A} \beta$ amyloid aggregates. lysis buffer (50\% dimethylformamide and $20 \%$ SDS, $\mathrm{pH} 7.4$ ), and the plates were incubated overnight, after which MTT reduction was determined in a Uniskan microplate spectrophotometer at 540 and $650 \mathrm{~nm}$. Results are expressed as the percentage of control values.

Avian retina cell cultures. Primary cultures of retina cells were prepared following the protocol described previously (De Mello et al., 1976; Vogel and Nirenberg, 1976; Puro et al., 1977). Briefly, 8-d-old chick embryo retinas were dissected under sterile conditions, cleared from pigment epithelium, and placed in a $\mathrm{Ca}^{2+}$ - and $\mathrm{Mg}^{2+}$-free salt-balanced medium (Sheffield and Moscona, 1970). Trypsin, to a final concentration of $0.05 \%$, was added to the medium and incubated at $37^{\circ} \mathrm{C}$ for $8 \mathrm{~min}$. The trypsinized tissue was then centrifuged at $500 \times g$ for $1 \mathrm{~min}$, and the supernatant was discarded. The pellet was resuspended in $5 \mathrm{ml}$ of Eagle's basal medium plus 5\% FCS and mechanically dissociated by pipetting the tissue 10 times with a $5 \mathrm{ml}$ pipette (Paes de Carvalho and De Mello, 1982). The number of cells per $35 \mathrm{~mm}$ plastic dish was $\sim 30 \times 10^{6}$ in $2 \mathrm{ml}$ of medium. The plates were then transferred to a humidified atmosphere of $95 \%$ air and $5 \% \mathrm{CO}_{2}$ at $37^{\circ} \mathrm{C}$. The medium was changed every other day.

Cytotoxicity assays in retina cells. For the cytotoxicity assays, $6 \mathrm{~d}$ retina cell cultures were treated with either AChE-A $\beta$ complexes or $\beta$-amyloid fibrils, previously aged for $5 \mathrm{~d}$ and added to the wells at a final $\mathrm{A} \beta$ peptide concentration of $2.5 \mu \mathrm{M}$ and incubated for $24 \mathrm{hr}$ at $37^{\circ} \mathrm{C}$ (Campos et al., 1997). Then retina cells were analyzed by phase-contrast microscopy (20× magnification) using an Olympus inverted microscope. Phasecontrast images were photographed with Kodak (Rochester, NY) Ektachrome $64 \mathrm{~T} 35 \mathrm{~mm}$ film.

\section{RESULTS}

\section{AChE Forms a stable complex with the amyloid fibrils}

Because we have previously shown that $\mathrm{AChE}$ is able to promote the aggregation of the $\mathrm{A} \beta$ peptide (Inestrosa et al., 1996b), in the present work we study the characteristics of the amyloid fibrils formed in the presence of AChE. To obtain amyloid fibrils, we performed kinetic stirred aggregation assays, following $\mathrm{A} \beta$ ag- gregation by turbidity (Jarrett et al., 1993; Evans et al., 1995), in the presence or absence of AChE. After incubation for $5 \mathrm{hr}$, $\mathrm{A} \beta_{1-40}$ peptide without $\mathrm{AChE}$ aggregated to a lesser extent (twofold less) than the peptide incubated with AChE (Fig. 1A). Fibrils formed in the presence of $\mathrm{AChE}$ were separated from soluble enzyme by velocity sedimentation in 5-20\% sucrose gradients (Fig. $1 B$ ), using a $70 \%$ sucrose cushion at the bottom of the tubes to isolate the high molecular weight amyloid-AChE complexes. Figure $1 B 1$ shows the sedimentation profile of native brain AChE (10.7 S), and Figure $1 B 2$ shows a high molecular weight $\mathrm{AChE}$ aggregate at the 20-70\% sucrose interface. Using ${ }^{125} \mathrm{I}-\mathrm{A} \beta$ peptide these $\mathrm{AChE}$ aggregates were shown to cosediment with a labeled high molecular weight amyloid aggregate (Fig. 1B3). The radioactivity detected in the low-density side of the gradient probably reflects the distribution of soluble $\mathrm{A} \beta$ or small $\mathrm{A} \beta$ aggregates. At least $58 \%$ of the $\mathrm{AChE}$ activity present in these gradients appeared associated with the $\mathrm{A} \beta$ fibrils, suggesting that $\mathrm{AChE}$ is able to bind and interact with the amyloid aggregates forming a macromolecular complex. The fraction of $\mathrm{AChE}$ incorporated into the $\mathrm{AChE}-\mathrm{A} \beta$ complexes was established by extensive washing to remove noncomplexed AChE. Table 1 shows that $\sim 78 \%$ of AChE activity remains associated with the complexes. When ${ }^{125} \mathrm{I}$-AChE was used to estimate the amount of enzyme incorporated into the fibrils, at least $50 \%$ of the initial radioactivity was found associated with the complexes. These results indicate that $\mathrm{AChE}$ forms a complex with the $\mathrm{A} \beta$ fibrils in vitro, with an average of $60 \%$ of the AChE becoming incorporated into the amyloid fibrils. The stoichiometric ratio of $\mathrm{AChE} / \mathrm{A} \beta$ in the final complexes was $\sim 1: 1000$. 


\begin{tabular}{|c|c|c|c|c|}
\hline Fraction & $\begin{array}{l}\text { AChE } \\
\text { activity } \pm \text { SD (U) }\end{array}$ & $\%$ of the initial & $\begin{array}{l}\mathrm{AChE} \\
(\mathrm{cpm} \pm \mathrm{SD})\end{array}$ & $\%$ of the initial \\
\hline Initial & $1.941 \pm 0.480$ & 100.00 & $686.5 \pm 131.6$ & 100.00 \\
\hline $\mathrm{SN}$ & $0.228 \pm 0.106$ & 10.78 & $329.9 \pm 98.6$ & 48.05 \\
\hline W1 & $0.023 \pm 0.002$ & 1.18 & $21.0 \pm 1.9$ & 3.05 \\
\hline W2 & $0.005 \pm 0.004$ & 0.26 & $3.0 \pm 0.3$ & 0.43 \\
\hline W3 & $0.001 \pm 0.002$ & 0.05 & & \\
\hline $\mathrm{A} \beta_{1-40}$ aggregates & $1.553 \pm 0.611$ & 78.00 & $341.7 \pm 70.9$ & 49.77 \\
\hline
\end{tabular}

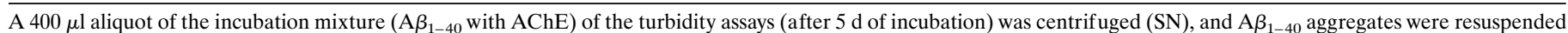

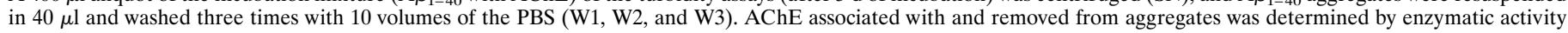
by the method of Ellman et al. (1961). The results are the mean \pm SD of four or five experiments.

Table 2. Solubilization of AChE from $\mathrm{A} \boldsymbol{\beta}_{1-40}$ aggregates

\begin{tabular}{lcc} 
& $\begin{array}{l}\text { (cpm in the } \\
\text { supernatant/ } \\
\text { cpm total } \times \\
100(\% \pm \mathrm{SD})\end{array}$ & $\begin{array}{l}\text { (activity in the } \\
\text { supernatant/ } \\
\text { total activity } \\
\times 100(\%)\end{array}$ \\
\hline PBS & $3.20 \pm 0.65$ & 2.19 \\
PBS-1\% Tween 20 & $9.30 \pm 3.96$ & 12.01 \\
PBS-1\% Triton X-100 & $15.42 \pm 2.23$ & 32.18 \\
$1 \mathrm{M} \mathrm{NaCl}$ & $1.82 \pm 0.51$ & 2.87 \\
$2 \mathrm{M} \mathrm{MgCl} 2$ & $1.73 \pm 0.31$ & 1.30 \\
$8 \mathrm{M}$ urea & $12.5 \pm 0.38$ & $\mathrm{ND}$ \\
$1 \%$ SDS & $84.15 \pm 8.48$ & $\mathrm{ND}$ \\
$6 \mathrm{M}$ guanidine-HCl & $57.45 \pm 20.10$ & $\mathrm{ND}$ \\
$6 \mathrm{M}$ guanidine isothiocyanate & $82.25 \pm 14.87$ & $\mathrm{ND}$
\end{tabular}

Amyloid aggregates formed in presence of ${ }^{125} \mathrm{I}-\mathrm{AChE}$ were washed with PBS three times. After washing with 10 volumes of each solution, the AChE solubilized was determined in the supernatant after centrifugation by counts per minute and activity. The results represent the mean \pm SD of three or four experiments. ND, Not determined.

The stability of the complexes was analyzed by performing incubations in the presence of strong dissociating agents, some of which had previously been shown to dissociate $\mathrm{A} \beta$ polymers obtained from AD brain (Masters et al., 1985). AChE was followed by enzymatic activity or by following ${ }^{125} \mathrm{I}-\mathrm{AChE}$ radioactivity. The interaction of the enzyme with the $\mathrm{A} \beta$ fibrils was resistant to high ionic strength conditions, including $1 \mathrm{M} \mathrm{NaCl}$ and $2 \mathrm{M} \mathrm{MgCl}_{2}$ (Table 2), and was only partially affected by PBSTween 20 and PBS-Triton X-100. These detergent buffers were able to remove $\sim 10$ and $20 \%$, respectively, of the total AChE activity associated with the amyloid aggregates. Urea $(8 \mathrm{M}) \mathrm{re}-$ leased $\sim 12 \%$ of the $\mathrm{AChE}$ activity from the $\mathrm{A} \beta$ fibrils, and the chaotropic agent $6 \mathrm{M}$ guanidine- $\mathrm{HCl}$ released $57 \%$. On the other hand, SDS and guanidine isothiocyanate released 84 and $82 \%$, respectively, of the enzyme present in the complexes. These results are consistent with the notion that stable $\mathrm{AChE}-\mathrm{A} \beta$ complexes are formed when AChE is used to accelerate the formation of amyloid aggregates.

\section{The association of AChE with the amyloid aggregates is an early event during fibril formation}

To investigate how early during the $\mathrm{A} \beta-\mathrm{AChE}$ complex formation the enzyme becomes associated with the fibrils, $40 \mu \mathrm{l}$ aliquots were taken from turbidity assays at different incubation times, and the AChE activity present in the pellets was determined. Figure 2 shows that the AChE activity present in the incubation mixture became rapidly associated with the $\mathrm{A} \beta$ aggregates. In fact, as early as $30 \mathrm{~min}$ after mixing, most of the AChE added was

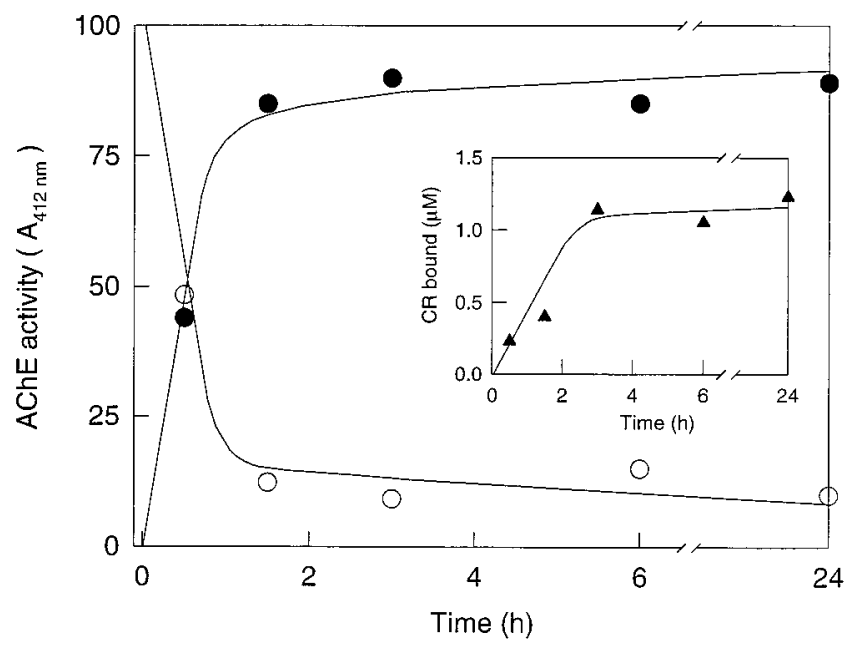

Figure 2. Temporal dependence of AChE-A $\beta$ fibril complex formation. Turbidimetric stirred assays of $\mathrm{A} \beta$ with $\mathrm{AChE}$ were incubated for $90 \mathrm{~min}$. Then aliquots of $40 \mu \mathrm{l}$ were taken at different incubation times, diluted in $400 \mu \mathrm{l}$ of PBS, and centrifuged, and AChE activity was determined in the fibril pellet $(\mathbf{O})$ and the supernatant fraction $(\bigcirc)$ by the assay of Ellman et al. (1961). The amyloid character of the aggregates formed in the presence of AChE was determined by Congo red assays (inset) in the pellet fraction.

present in the precipitate fraction containing amyloid aggregates (Fig. 2, O). Concomitant with this, most of the free enzyme was removed from the soluble fraction (Fig. 2, ○). The amyloid character of the $\mathrm{A} \beta$ aggregates formed in the presence of $\mathrm{AChE}$ was determined by Congo red assays (Fig. 2, inset). This result indicates that the formation of $\mathrm{AChE}-\mathrm{A} \beta$ complexes is an early event during the $\mathrm{A} \beta$ aggregation process.

\section{Morphological examination of the AChE-A $\beta$ complexes}

The structure of the $\mathrm{AChE}-\mathrm{A} \beta$ complexes was examined under fluorescence microscope after staining with thioflavine-T; the aggregates showed a strong green fluorescence, indicating their amyloid character (Fig. 3A,B) (Roher et al., 1986). When these aggregates were histochemically stained for AChE using the method of Karnovsky and Roots (1964), they showed the typical brown of this staining reaction (Fig. 3C,D), confirming the presence of $\mathrm{AChE}$ activity in the $\mathrm{AChE}-\mathrm{A} \beta$ complexes. Amyloid aggregates generated in the absence of $\mathrm{AChE}$ did not show such histochemical staining (data not shown). Finally, we examined the amyloid filaments to establish whether the filaments were indeed complexed to AChE. Using immunogold electron microscopy with antibodies directed against $\mathrm{AChE}$, small specks could be seen in the AChE-A $\beta$ complexes (Fig. $4 A$ ) and AChE-A $\beta$ fibers 

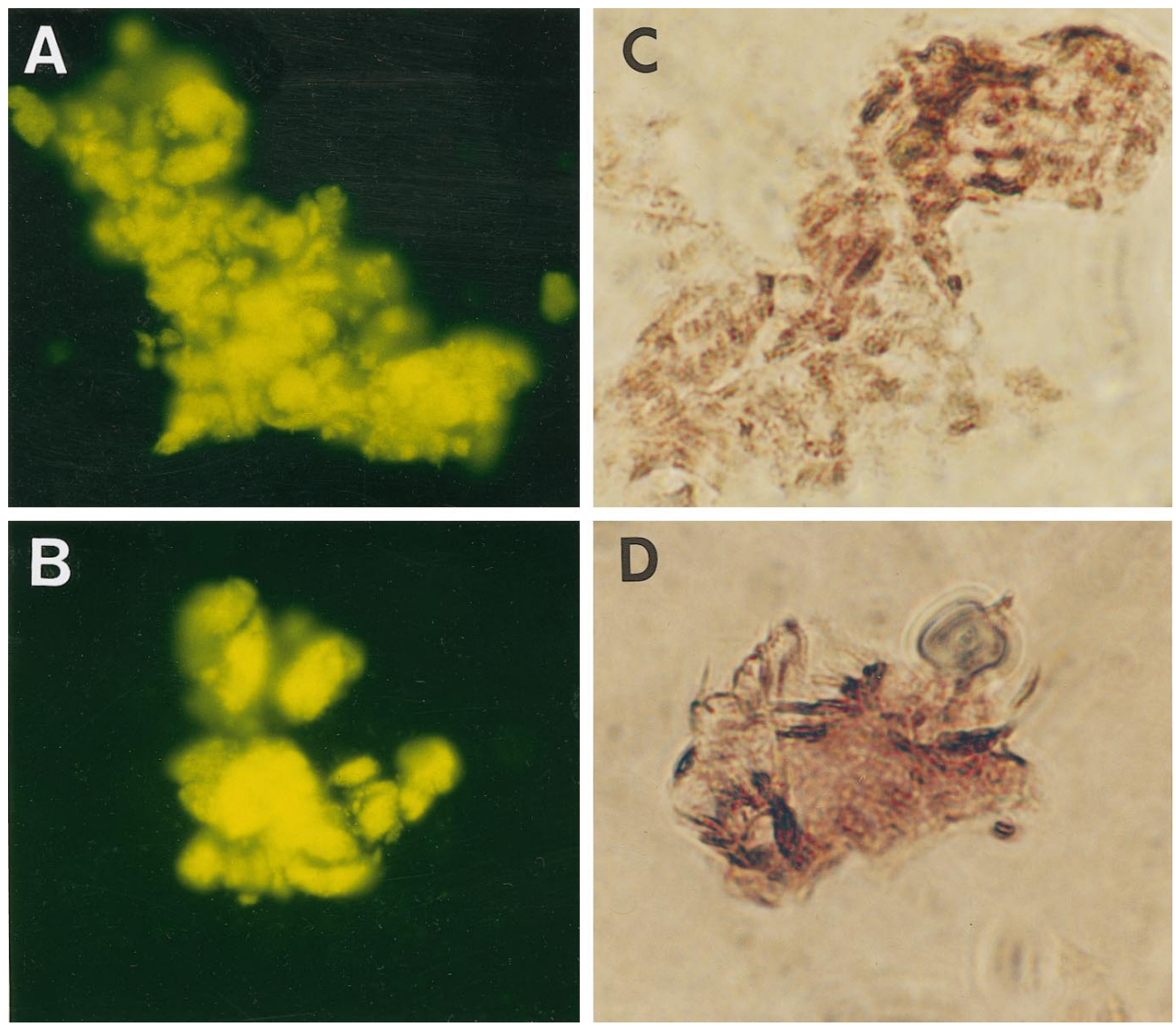

Figure 3. Thioflavine-T fluorescence and AChE histochemical staining of the AChE-A $\beta$ complexes. $A, B$, Amyloid aggregates formed in a kinetic stirred assay were washed three times with PBS and then incubated for $4 \mathrm{~min}$ in a solution containing an excess of thioflavine-T (5 mg $/ \mathrm{ml})$. Samples were examined under an Axioplan fluorescence microscope (D-7082; Zeiss, Oberkochen, Germany) at 400× magnification. $C, D$, Amyloid aggregates from a kinetic stirred assay were washed three times with PBS, after which the fibrils were stained for AChE with the histochemical staining reaction of Karnovsky and Roots (1964).

(Fig. 4B). A $\beta$ complexes alone did not show specific labeling (Fig. $4 C)$. The electron microscopic examination of the amyloid filaments demonstrated the existence of the $\mathrm{AChE}-\mathrm{A} \beta$ complex.

\section{Enzymatic properties of the AChE present in the AChE-A $\beta$ complexes}

There are previous studies indicating that the AChE associated with the amyloid deposits of AD brains appears to have unique properties (Geula and Mesulam, 1989; Kalaria et al., 1992). Therefore, a thorough biochemical and pharmacological analysis of the amyloid-associated AChE was performed. Kinetic studies were performed, and the effects of different inhibitors, excess substrate, and low $\mathrm{pH}$ were evaluated. Figure $5 \mathrm{~A}$ shows the Lineweaver-Burk plot $(1 / \mathrm{V}$ vs $1 / S)$ obtained for soluble AChE and $\mathrm{A} \beta$-complexed $\mathrm{AChE}$. It is apparent that the kinetic parameters change, and that the $K_{\mathrm{m}}$ and $V_{\max }$ values for the amyloid were higher than for the soluble AChE (Table 3). When the $\mathrm{AChE}-\mathrm{A} \beta$ complexes were incubated under different $\mathrm{pH}$ conditions, it became clear that the enzyme associated with amyloid was more resistant to low-pH conditions than the free enzyme (Fig. $5 B$ ). When the incubations were performed in the presence of increasing substrate concentrations, the $\mathrm{A} \beta$-associated AChE was more resistant to inhibition by excess acetylthiocholine (Fig. $5 C$ ). A shift toward the right is observed on the rising side of the curve (in the lower concentration range), whereas on the descending side of the curve (high concentrations), the data are most coincident (although not identical) for both $\mathrm{AChE}$ and $\mathrm{AChE}-\mathrm{A} \beta$. Moreover, the activity peak for $\mathrm{AChE}-\mathrm{A} \beta$ is sharper and narrower than that for $\mathrm{AChE}$ alone. This behavior probably indicates that once the substrate has gained access (in the higher concentration range), the effects of excess substrate on both $\mathrm{AChE}$ and $\mathrm{AChE}-\mathrm{A} \beta$ are very similar if not identical. However, at lower concentrations, it is more difficult for the substrate to bind complexed $\mathrm{AChE}$ than free $\mathrm{AChE}$ for reasons of physical hindrance.

Finally, the AChE associated with amyloid fibrils appeared more resistant to inhibition by anti-cholinesterase agents (Table 3). In particular, when fasciculin (a 61 amino acid peptide isolated from mamba venom (Rodriguez Ithurralde et al., 1983; Dajas et al., 1987) was used, a much higher concentration (micromolar) was required to inhibit the amyloid-associated $\mathrm{AChE}$ than the free soluble enzyme (nanomolar) (Fig. 6A). A similar trend was observed when monoclonal antibody 25B1 directed against $\mathrm{AChE}$ (Gentry et al., 1995), which also blocks the amyloid formation elicited by the enzyme, (Reyes et al., 1997) was used (Fig. 6B). The $K_{i}$ values obtained for the other anti-cholinesterase agents, Tacrine, edrophonium, and propidium, were 16-, 14-, and 9-fold higher, respectively, for the complexed AChE than for the soluble enzyme (Table 3 ). In all cases, a $\sim 5$ - to 10-fold increase in the substrate or inhibitor concentrations was required to reach the same level of AChE inhibition when AChE was associated with 

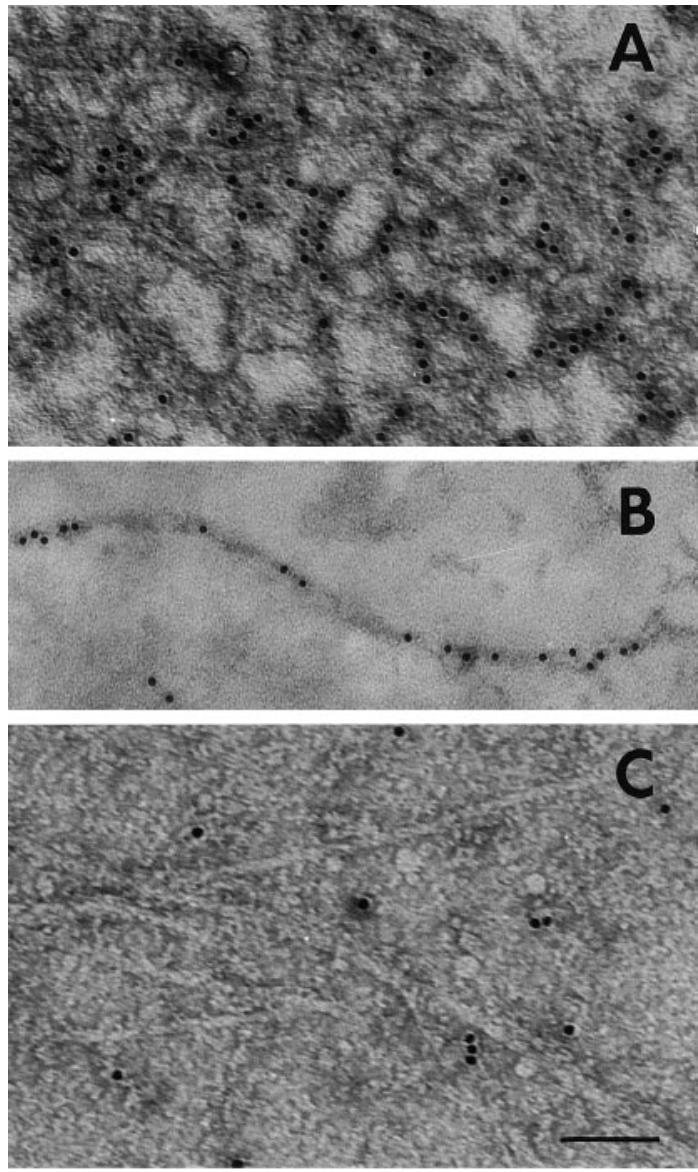

Figure 4. Immunogold labeling of the $\mathrm{AChE}-\mathrm{A} \beta$ complexes. $A$, $\mathrm{AChE}-\mathrm{A} \beta$ complexes were labeled with a polyclonal antibody raised against $\mathrm{AChE}$, followed by an anti-IgG antibody conjugated to $10 \mathrm{~nm}$ colloidal gold particles, and were visualized by negative staining. $B$, Select example of an amyloid fiber labeled with anti-AChE conjugated to gold particles. $C$, Control sample of high molecular mass $\mathrm{A} \beta$ aggregates without AChE that were treated with the same specific antibody as above. In each case, $10 \mu \mathrm{l}$ aliquots taken from an $\mathrm{A} \beta$ peptide kinetic stirred aggregation assay, performed either in the presence or absence of AChE, were adsorbed onto 300-mesh Formvar-coated grids, negative-stained with $2 \%$ uranyl acetate, and viewed for fibrils with a Philips electron microscope. Scale bar: $A, C, 90 \mathrm{~nm} ; B, 80 \mathrm{~nm}$.

$\mathrm{A} \beta$ aggregates. That is to say, the effects were independent of the structure or size of the inhibitor molecules under consideration. As such, these results are consistent with a physical phenomenon, i.e., the location or occlusion of the enzyme enmeshed within a fibrillar environment. In a broad context, our results are consistent with the idea that the association of $\mathrm{AChE}$ with $\mathrm{A} \beta$ fibrils determines a change in its enzymatic properties, as occurs in the senile plaques of Alzheimer's brain.

\section{$A C h E-A \beta$ complexes exhibit increased neurotoxicity in relation to amyloid fibrils alone}

Its has been demonstrated that amyloid fibrils are toxic to neuronal cells in culture (Lorenzo and Yankner, 1994; Yankner, 1996), and several studies have shown a strong correlation between $\mathrm{A} \beta$ neurotoxicity and the aggregation state of the $\mathrm{A} \beta$ peptide (Busciglio et al., 1992; Mattson et al., 1992; Pike et al., 1993). Hence we hypothesized that the fibrils of the AChE-A $\beta$ complexes would be neurotoxic (Inestrosa et al., 1997), and to evaluate this point, we performed experiments using $\mathrm{AChE}-\mathrm{A} \beta$
A

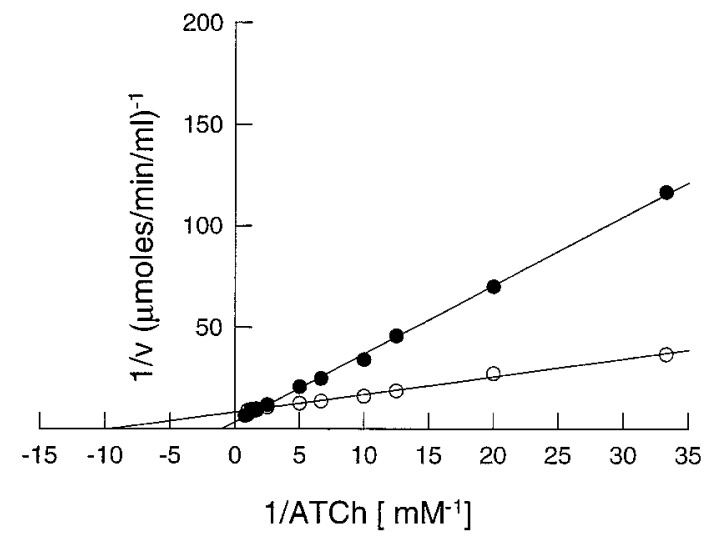

B

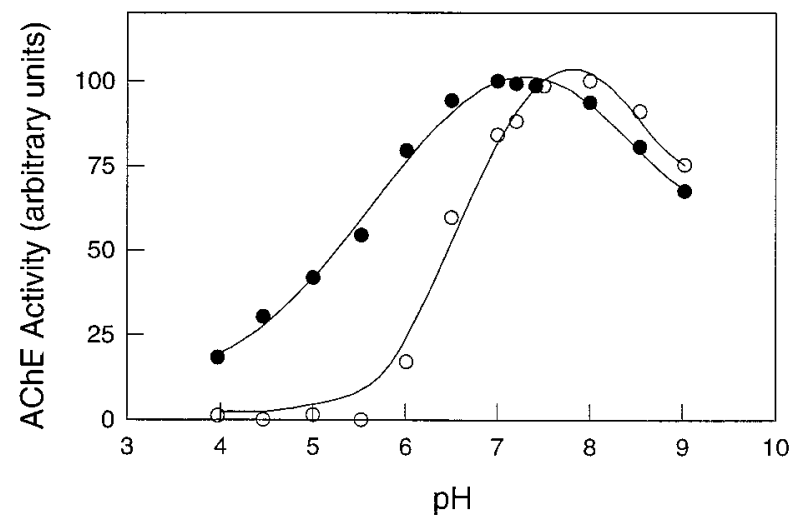

C

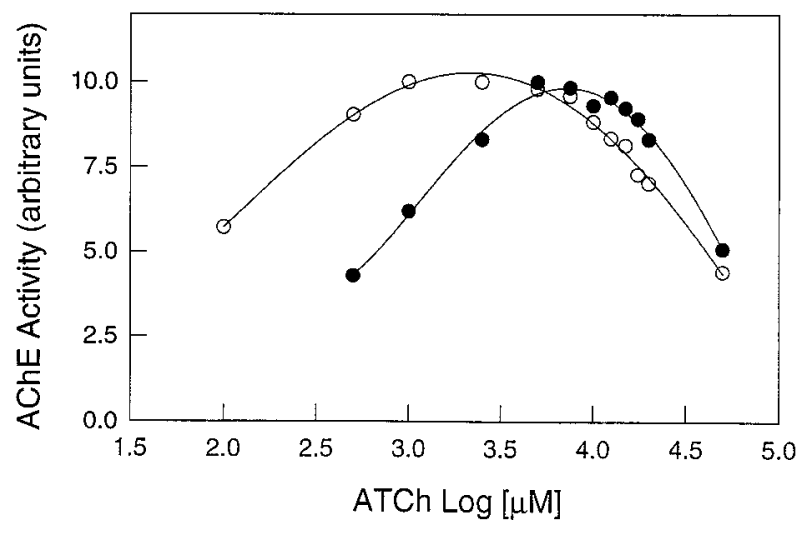

Figure 5. Biochemical characterization of the AChE activity associated with amyloid- $\beta$ fibrils. AChE-A $\beta$ complexes were washed exhaustively with PBS using four cycles of centrifugation and resuspension to remove noncomplexed AChE, and then amyloid-associated AChE activity was studied (@). Soluble native brain AChE was used as control (O). $A$, Lineweaver-Burk (double-reciprocal) plots. AChE activity, free and associated with amyloid- $\beta$ fibrils, was measured over a range of substrate concentrations. $B, \mathrm{pH}$ dependence. Optimal $\mathrm{pH}$ for $\mathrm{AChE}$ and $\mathrm{AChE}-\mathrm{A} \beta$ complex activity was determined over a $\mathrm{pH}$ range of 4.0-9.0 in phosphate buffer. $C$, Activity of $\mathrm{AChE}$ as a function of substrate concentration. The rate of hydrolysis is plotted as a log function of acetylthiocholine substrate concentration. The bell-shaped curves show that both free $\mathrm{AChE}$ and the $\mathrm{AChE}-\mathrm{A} \beta$ complexes are inhibited by excess substrate. However, the $\mathrm{AChE}-\mathrm{A} \beta$ complexes require higher acetylthiocholine concentrations for optimal activity than the free enzyme.

complexes versus $\mathrm{A} \beta$ aggregates in neuronal cell cultures. First, rat pheochromocytoma (PC12) cell cultures (Greene and Tischler, 1976) were treated with fibrillar $\mathrm{A} \beta$ and $\mathrm{AChE}-\mathrm{A} \beta$ complexes. Cell viability was assessed by a decrease in their ability to 


\begin{tabular}{|c|c|c|}
\hline Parameter & $\mathrm{AChE}$ & $\begin{array}{l}\mathrm{AChE}-\mathrm{A} \beta \\
\text { complex }\end{array}$ \\
\hline \multicolumn{3}{|l|}{ Kinetic parameters } \\
\hline$K_{\mathrm{m}}(\mathrm{mM})$ & $0.097 \pm 0.007$ & $0.764 \pm 0.025^{*}$ \\
\hline$V_{\max }(\mu \mathrm{mol} / \mathrm{min} / \mathrm{ml})$ & $0.129 \pm 0.015$ & $0.222 \pm 0.029^{*}$ \\
\hline$K_{\mathrm{ss}}(\mathrm{mM})$ & $30.4 \pm 1.1$ & $48.1 \pm 8.5^{* *}$ \\
\hline Optimal pH & $7.5-8.0$ & 7.0 \\
\hline Activity at pH $5.0(\%)$ & $3.2 \pm 0.8$ & $41.1 \pm 3.0^{*}$ \\
\hline \multicolumn{3}{|l|}{$\mathrm{IC}_{50}$ values } \\
\hline Tacrine (nм) & $445.0 \pm 17.6$ & $1074.8 \pm 73.3^{*}$ \\
\hline Edrophonium $(\mu \mathrm{M})$ & $5.36 \pm 0.48$ & $17.6 \pm 4.6^{* * *}$ \\
\hline Propidium $(\mu \mathrm{M})$ & $34.6 \pm 1.20$ & $72.0 \pm 4.8^{*}$ \\
\hline \multicolumn{3}{|l|}{ Inhibition coefficients $\left(K_{i}\right)$} \\
\hline Tacrine (nM) & 51.0 & 542.4 \\
\hline Edrophonium $(\mu \mathrm{M})$ & 0.61 & 8.90 \\
\hline Propidium $(\mu \mathrm{M})$ & 3.96 & 36.3 \\
\hline
\end{tabular}

The $K_{\mathrm{m}}$ and $V_{\max }$ was determined from Lineweaver-Burk plots (1/V vs $\left.1 / S\right)$, with $0.03-1.0 \mathrm{~mm}$ acetylthiocholine. $K_{\mathrm{ss}}$ was determined by plotting of $1 / V$ as a function of substrate concentration $(0.1-50 \mathrm{~mm})$. For determination of $\mathrm{IC}_{50}$ values, samples were incubated with appropriate concentrations of the various inhibitors for $30 \mathrm{~min}$ at room temperature, and the AChE activity was determined colorimetrically. $K_{\mathrm{i}}$ values are determined as specified in Materials and Methods. Values represent means $\pm \mathrm{SD}$ of four to six separate assays made in duplicate for $\mathrm{AChE}$ and three to five for $\mathrm{AChE}-\mathrm{A} \beta$ complex.

*Significantly different from control with $p<0.001$ by nonparied Student's $t$ test; ${ }^{* * *} p<0.01 ; * * p<0.05$.

reduce MTT (Mosmann, 1983). As shown in Figure 7, A $\beta$ neurotoxicity was dose-dependent in the range of 1-25 $\mu \mathrm{M}$, and cell toxicity decreased to $\sim 27 \%$ of control cells measured in the absence of $\mathrm{A} \beta$ peptide. However, when the PC12 cells were treated with $\mathrm{A} \beta$ fibrils formed in the presence of $\mathrm{AChE}$, a major decrease in MTT reduction was apparent in comparison with A $\beta$ fibrils alone. This effect was dependent on the concentration of both the $\mathrm{A} \beta$ peptide and the AChE used in the complexes; the highest concentration of $\mathrm{AChE}$ added to the cells in complexed form was $25 \mathrm{~nm}$, in comparison with $25 \mu \mathrm{M} \mathrm{A} \beta$ peptide. At this concentration, cell survival was minimal, and the cytotoxic effect of the fibrillar $\mathrm{A} \beta$ was enhanced almost twofold, whereas $\mathrm{AChE}$ added alone, at $25 \mathrm{~nm}$, did not show a toxic effect (data not shown). Further experiments were performed using primary neuronal cultures to discard any possibility of a specific susceptibility of PC12 cells to the AChE-amyloid aggregates. The effect of the $\mathrm{AChE}-\mathrm{A} \beta$ complexes was studied in chick primary cultures of retina cells (Vogel and Nirenberg, 1976; Puro et al., 1977; Paes de Carvalho and De Mello, 1982). Figure $8 A$ shows a control $6 \mathrm{~d}$ neuronal cell culture. These cells are known to display abundant neurite outgrowth and present several types of neurotransmitter receptors, including GABA, dopamine, and acetylcholine of both nicotinic and muscarinic sort (Enna and Snyder, 1976; Vogel et al., 1976; Sugiyama et al., 1977; Makman et al., 1980). After 24 hr of treatment with $\beta$-amyloid fibrils $(2.5 \mu \mathrm{M})$, the retina cells showed a clear loss of neurites and a decrease in cell density (Fig. $8 B)$. However, when the neuronal cultures were exposed to $\mathrm{AChE}-\mathrm{A} \beta$ complexes, aged for $5 \mathrm{~d}$, dramatic changes were observed. Only a minimal number of cells were seen to present neurites, and most cells were dead after $24 \mathrm{hr}$ of culture (Fig. $8 C$ ). Summarizing, studies with two very different cell culture systems indicate that the $\mathrm{AChE}-\mathrm{A} \beta$ complex is more toxic than $\mathrm{A} \beta$ fibrils alone, suggesting that the incorporation of AChE into Alzhei-
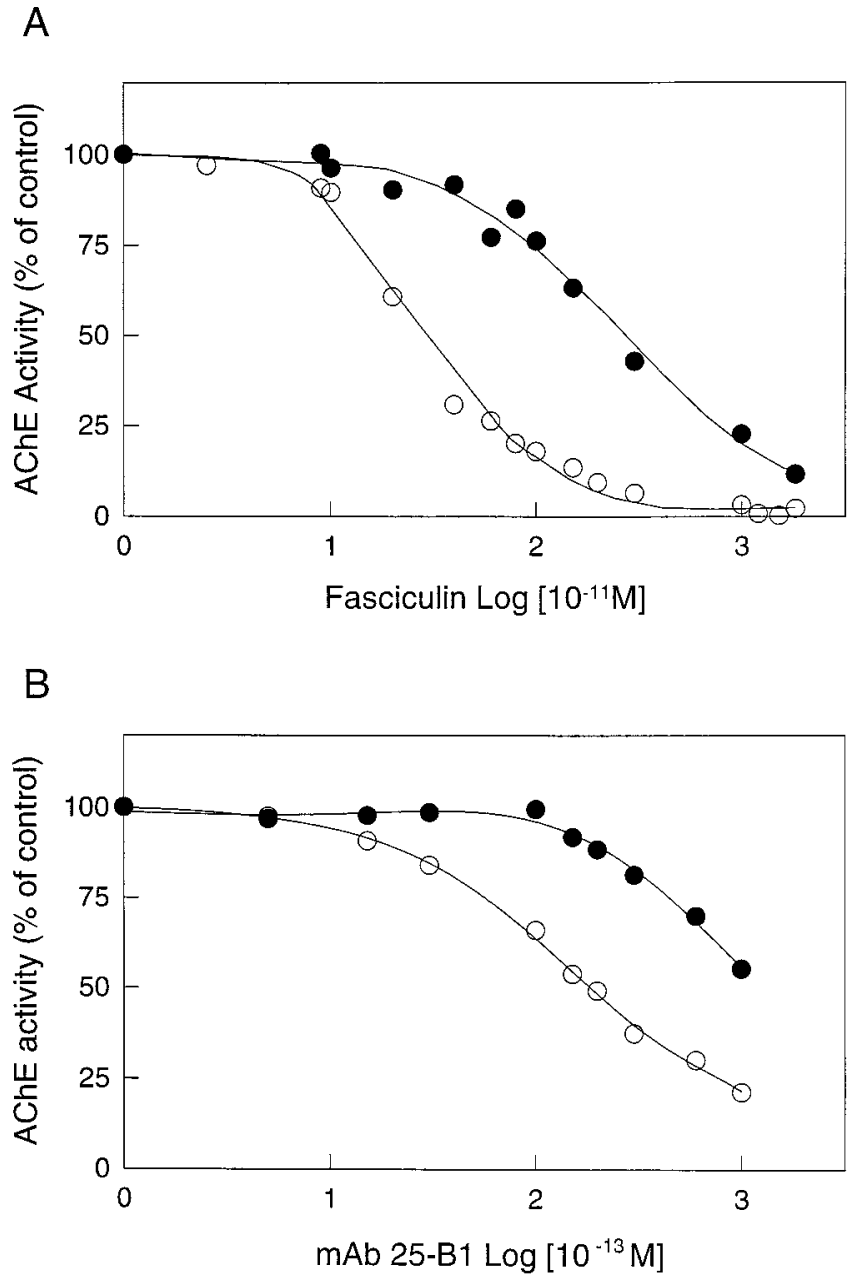

Figure 6. Inhibition of the $\mathrm{AChE}-\mathrm{A} \beta$ complex by fasciculin and the monoclonal antibody 25-B1 ( $m A b$ 25-B1), two peripheral anionic binding site ligands. The activity is plotted as a function of fasciculin $(A)$ and $\mathrm{mAb}$ 25-B1 $(B)$ concentrations. Free $\mathrm{AChE}(\bigcirc)$ and $\mathrm{AChE}-\mathrm{A} \beta$ complexes $(\bullet)$ are both inhibited by fasciculin and $\mathrm{mAb} 25-\mathrm{B} 1$. However, the AChE-A $\beta$ complexes require higher concentrations of both compounds to reach the same level of inhibition as free $\mathrm{AChE}$. The $\mathrm{IC}_{50}$ values for free $\mathrm{AChE}$ were $249 \pm 15 \mathrm{pM}$ for fasciculin and $19.0 \pm 0.5 \mathrm{pM}$ for mAb 25-B1. The corresponding values for the $\mathrm{AChE}-\mathrm{A} \beta$ complexes were $2746 \pm 28 \mathrm{pm}$ for fasciculin and $>100 \mathrm{pm}$ for $\mathrm{mAb} 25-\mathrm{B} 1$. The $\mathrm{IC}_{50}$ values represent the mean $\pm \mathrm{SD}$ of three identical samples run in separate experiments.

mer's amyloid fibrils could lead to an increase in their neurotoxic properties. The AChE associated with the $\beta$-amyloid deposits present in Alzheimer's brain may indeed be a relevant factor in triggering the neurodegeneration induced by senile plaques in specific regions of the brain.

\section{DISCUSSION}

\section{The interaction of $\mathrm{AChE}$ with $\mathrm{A} \boldsymbol{\beta}$ aggregates results in the formation of a stable AChE-A $\boldsymbol{\beta}$ complex}

In the present study, the ability of purified $\mathrm{AChE}$ to form an $\mathrm{AChE}-\mathrm{A} \beta_{1-40}$ complex was demonstrated. $\mathrm{AChE}$ was able to bind and interact with amyloid aggregates forming stable macromolecular complexes. In fact, such complexes were joined by strong intermolecular bonds because they were partially disrupted only by chaotropic agents ( $6 \mathrm{~m}$ guanidine- $\mathrm{HCl}$ and $6 \mathrm{~m}$ guanidine isothiocyanate), agents known to be able to solubilize amyloid cores from Alzheimer's brain (Masters et al., 1985) and to disrupt 


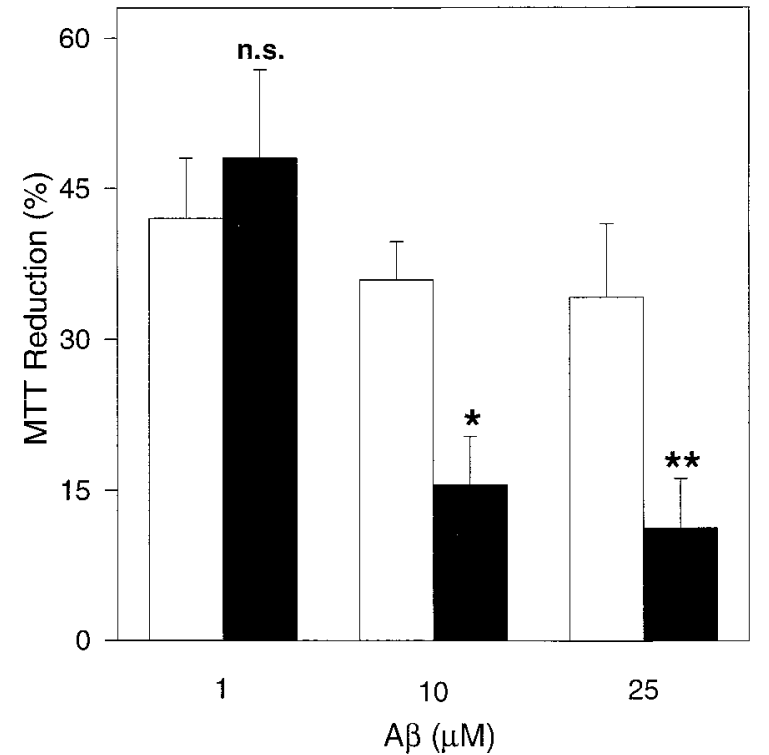

Figure 7. $\mathrm{AChE}-\mathrm{A} \beta$ complexes are more toxic than $\mathrm{A} \beta$ fibrils alone in PC12 cells. Rat pheochromocytoma PC12 cells were treated with $\mathrm{A} \beta$ amyloid fibrils as a control (white bars) or with $\mathrm{AChE}-\mathrm{A} \beta$ amyloid fibrils (black bars) for $48 \mathrm{hr}$ at different $\mathrm{A} \beta$ concentrations. The cell viability after treatment was measured by the MTT reduction assay. Significantly different from control: ${ }^{*} p<0.05 ;{ }^{* *} p<0.001$ by nonpaired Student's $t$ test; n.s., not significant.

amyloid fibrils (Naiki et al., 1991), and by SDS detergent, able to disassemble amyloid fibrils formed by the $\mathrm{A} \beta_{1-40}$ peptide (Soreghan et al., 1994). High ionic strength buffers were unable to dissociate the enzyme from these complexes. A very high percentage of the initial AChE present during fibrillogenesis remained bound to the $\mathrm{A} \beta$ fibrils, as estimated by the incorporation of ${ }^{125} \mathrm{I}-\mathrm{AChE}$ or by enzymatic activity measurements. Immunogold labeling confirmed that AChE was tightly bound to the amyloid fibrils.

It would appear that aggregation with AChE is not a promiscuous process but, rather, thermodynamically favored, because only a small amount of $\mathrm{AChE}$ is required to promote aggregation (Fig. 1). In fact, the stoichiometric ratio of $\mathrm{AChE} / \mathrm{A} \beta$ in the final complexes was $\sim 1: 1000$, and it is possible that this ratio represents the successive incorporation of $\mathrm{A} \beta$ monomers onto an initial $\mathrm{A} \beta$ fibril containing an $\mathrm{AChE}-\mathrm{A} \beta$ complex. A morphological examination of such complexes showed that their structural properties were typical of amyloid; i.e., they displayed fluorescent staining with thioflavine-T and a fine structure similar to that of amyloid $\mathrm{A} \beta$ fibrils, as determined by negative staining under the electron microscope. Finally, our biochemical data indicated that the incorporation of AChE into the amyloid complex was an early event during the polymerization and growth of the fibrils. This suggests a role for the $\mathrm{AChE}-\mathrm{A} \beta$ complex at the beginning of the amyloidogenic process, whereby $\mathrm{AChE}$ may act as a heterogeneous nucleus, increasing the rate of fibrillogenesis and stabilizing the growing amyloid fibrils. Consistent with this possibility is the finding that when AChE was incubated with partially formed amyloid fibrils, only a small proportion of the enzyme (2\%) was able to bind to the fibrils (data not shown) (R. Alarcón and N. C. Inestrosa, unpublished results). Such behavior can be expected from heteronucleators in a polymerization process, which act during the initial nucleation phase of filament formation (Ferrone et al., 1985).
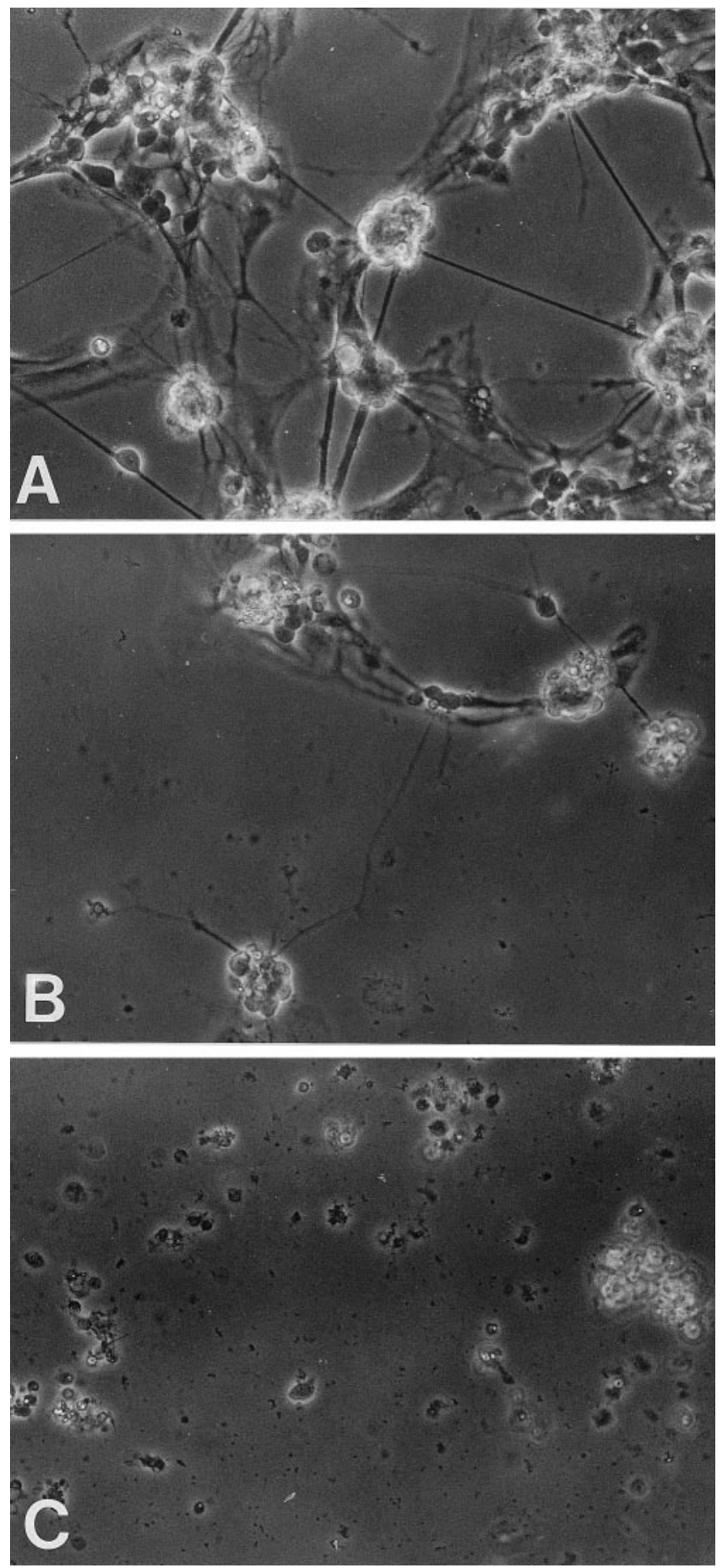

Figure 8. $\mathrm{AChE}-\mathrm{A} \beta$ complexes are more toxic than $\mathrm{A} \beta$ fibrils alone in primary cultures of retina cells. Six-day chick retina cell cultures were incubated for $24 \mathrm{hr}$ in a medium supplemented with PBS as a control $(A)$, $\beta$-amyloid fibrils $(2.5 \mu \mathrm{M})(B)$, and AChE-A $\beta$ complexes $(2.5 \mu \mathrm{M}$ for the $\mathrm{A} \beta$ peptide) ( $C$ ). The retina cell cultures were observed by phase contrast microscopy using $40 \times$ magnification under an Olympus inverted microscope. Representative photographs are shown.

The formation of an $\mathrm{AChE}-\mathrm{A} \beta$ complex in vitro is reminiscent of the formation of apoE-A $\beta$ complexes observed in vivo (Naslund et al., 1995; Castaño et al., 1995). In this case, the existence of the apoE-A $\beta$ complex together with genetic evidence has been used to support a role for apoE as a risk factor in AD (Selkoe, 1996). 


\section{The AChE-A $\beta$ complex changes the biochemical properties of the enzyme}

The formation of an $\mathrm{AChE}-\mathrm{A} \beta$ complex is entirely consistent with the fact that $\mathrm{AChE}$ and butyrylcholinesterase have been identified within $A \beta$ deposits, such as those found in preamyloid diffuse and mature senile plaques and cerebral blood vessels (Morán et al., 1993; Geula and Mesulam, 1994), and emphasizes the potential relevance of AChE in AD. Most of the AChE found in senile plaques is associated with the amyloid cores, and only a small portion is associated with the neuritic components at the periphery of the plaques (Ulrich et al., 1990; Carson et al., 1991). Histochemical studies have demonstrated that the AChE associated with senile plaques differs from the enzyme found in normal fibers and neurons with respect to optimal $\mathrm{pH}$, inhibition by excess substrate, and inhibitor sensitivity (Mesulam et al., 1987; Geula and Mesulam, 1989; Schätz et al., 1989; Wright et al., 1993). Furthermore, biochemical studies have indicated that senile plaque-associated $\mathrm{AChE}$ is only partially extracted using collagenase digestions (Nakamura et al., 1990), heparan sulfate extractions (Kalaria et al., 1992), or high-salt buffers plus detergent (Mimori et al., 1997). Interestingly, the AChE present in the $\mathrm{AChE}-\mathrm{A} \beta$ complexes reported here showed unique properties similar to those of senile plaque-associated AChE. In fact, the complexed enzyme (1) presented $K_{\mathrm{m}}$ and $V_{\max }$ values higher than those of the free enzyme and was more resistant to (2) incubation under low $\mathrm{pH}$ conditions, (3) inhibition by anti-cholinesterase agents, and (4) inhibition by excess acetylthiocholine. Regarding the latter, the shift toward the right seen in the lower concentration side of the curve (Fig. $5 C$ ) suggests that the fibrils establish a physical barrier that hinders access of the substrate to the enzyme active site. This would explain why higher concentrations of acetylthiocholine are required and would also account for the reactions obtained with small organic inhibitors as well as larger ones. This physical trapping of the enzyme is also consistent with our observation (Fig. 2) that formation of the AChE-A $\beta$ complex is an early rather than late event in the fibrillogenic process. Maturation of the fibrils inhibits or precludes occlusion of the enzyme within $\mathrm{A} \beta$, whereas fibrils still in their initial phases retain the freedom to trap the enzyme. In addition, as indicated in Table 2, such a mechanism is distinct from the hydrophobic interactions typical of globular proteins and allows for the observation that not all denaturants, certainly not high-salt media, are able to solubilize the fibril components. Physical trapping of the enzyme could also account for the general observation that butyrylcholinesterase, which has no peripheral anionic binding site and displays different kinetic properties to $\mathrm{AChE}$, is also found amid amyloid fibrils. This theory is quite interesting, in that a structural gene defect in AChE, butyrylcholinesterase, or any other enzyme species caught midst the amyloid fibrils is not a requisite.

\section{AChE-A $\beta$ complexes increase the neurotoxicity of Alzheimer's fibrils}

The neurotoxicity of $\mathrm{A} \beta$ fibrils, together with the genetic evidence linking the amyloid precursor protein (APP) with AD, constitute the most relevant evidence to support a central role for the $\mathrm{A} \beta$ peptide in the pathogenesis of AD (Selkoe, 1996; Yankner, 1996). The observation, in AD brain studies, that neurodegenerative changes occur around senile plaques (Mann and Esiri, 1989) and the demonstration that $\mathrm{A} \beta$ together with various $\mathrm{C}$-terminal fragments of APP containing the A $\beta$ sequence is neurotoxic in cell cultures gave rise to the hypothesis that $\mathrm{A} \beta$ may be the primary cause of neuronal degeneration in AD (Yankner et al., 1989; Yankner, 1996). The neurotoxicity of $\mathrm{A} \beta$ is dependent on its aggregation state (Busciglio et al., 1992; Pike et al., 1993); it requires the assembly of $A \beta$ into amyloid fibrils, whereas nonfibrillar, amorphous aggregates of $\mathrm{A} \beta$ are not neurotoxic (Lorenzo and Yankner, 1994; Busciglio et al., 1995; Howllett et al., 1995). Our studies showing that the $\mathrm{AChE}-\mathrm{A} \beta$ complex presented a stronger cytotoxic effect than $\mathrm{A} \beta$ fibrils alone in both PC12 cells and primary retina cells indicate that the incorporation of AChE into amyloid fibrils changes their cytotoxic properties. This result is interesting because, although $\mathrm{A} \beta$ is a primary factor in the pathogenesis of AD (Selkoe, 1997), there are several reports suggesting that $A \beta$ deposition is not the sole determinant of disease progression. For example, substantial numbers of amyloid plaques occasionally appear in the brain in nondemented individuals, suggesting that $\mathrm{A} \beta$ deposition does not invariably lead to AD (Dickson et al., 1991). It is possible that this may be in part attributable to differences in the protein composition and structure of the plaques in demented and nondemented individuals (Barcikowska et al., 1989; Cras et al., 1991; Mesulam and Geula, 1994). Besides the capacity of AChE to modulate the toxicity of amyloid fibrils in vitro, other macromolecules such as apoE and apoJ have also been shown to regulate the toxicity of these fibrils. However, both of these elements were found to decrease amyloid toxicity in culture (Oda et al., 1995; Boggs et al., 1996; Puttfarcken et al., 1997), suggesting that an adequate balance between toxic elements and the microenvironment defines the final toxicity of $A \beta$ fibrils. In this context, it is interesting to mention that the potential role of $\mathrm{AChE}$ in AD is further supported by the fact that AChE systems, in particular those more vulnerable to $\mathrm{AD}$ such as the lightly stained neurons located in the entorhinal cortex, the CA1 and subiculum of the hippocampus, and the amygdala (Shen, 1994, Kasa et al., 1997), are the first to be affected in the pathological process of AD. Although the cellular mechanism of action of $\mathrm{A} \beta$ is not precisely understood, several processes have been proposed. In brief, $\mathrm{A} \beta$ has been shown to alter $\mathrm{Ca}^{2+}$ homeostasis (Mattson et al., 1992; Arispe et al., 1993), to enhance excitotoxic mechanisms (Mattson et al., 1992), and to generate free radicals (Hensley et al., 1994), although some controversy arises in the latter case (Sayre et al., 1997). Thus, AChE could affect the toxic signaling of $\mathrm{A} \beta$ at several points. An alternative possibility is that AChE per se activates neuronal cell death (Calderón et al., 1996, 1998). In any case, further experiments are required to fully understand the mechanisms by which the $\mathrm{AChE}-\mathrm{A} \beta$ complex is more toxic for neuronal cells in culture than $\mathrm{A} \beta$ fibrils alone.

\section{REFERENCES}

Abraham CR, Selkoe DJ, Potter H (1988) Immunochemical identification of the serine protease inhibitor $\alpha_{1}$-antichymotrypsin in the brain amyloid deposits of the Alzheimer's disease. Cell 52:487-501.

Alvarez A, Bronfman F, Pérez CA, Vicente M, Garrido J, Inestrosa NC (1995) Acetylcholinesterase, a senile plaque component, affects the fibrillogenesis of amyloid- $\beta$-peptides. Neurosci Lett 201:49-52.

Alvarez A, Opazo C, Alarcon R, Garrido J, Inestrosa NC (1997) Acetylcholinesterase promotes the aggregation of amyloid- $\beta$-peptide fragments by forming a complex with the growing fibrils. J Mol Biol 272:348-361.

Arispe N, Pollard HB, Rojas E (1993) Giant multilevel cation channels formed by Alzheimer disease amyloid $\beta$-protein $[\mathrm{A} \beta \mathrm{P}-(1-40)]$ in bilayer membrane. Proc Natl Acad Sci USA 90:10573-10577.

Barcikowska M, Wisniewski HM, Bancher C, Grundke-Iqbal I (1989) About the presence of paired helical filaments in dystrophic neurites participating in the plaque formation. Acta Neuropathol (Berl) 78:225-231. 
Boggs LN, Fuson KS, Baez M, Churgay L, Mcclure D, Becker G, May PC (1996) Clusterin (ApoJ) protects against in vitro amyloid $\beta(1-40)$ neurotoxicity. J Neurochem 67:1324-1327.

Busciglio J, Lorenzo A, Yankner BA (1992) Methodological variables in the assessment of beta amyloid neurotoxicity. Neurobiol Aging 13:609-612.

Busciglio J, Lorenzo A, Yeh J, Yankner BA (1995) $\beta$-Amyloid fibrils induce Tau phosphorylation and loss of microtubule binding. Neuron 14:879-888.

Calderón FH, De Ferrari GV, Luza SC, von Bernhardi R, Inestrosa NC (1996) Toxic effects of acetylcholinesterase in neuronal cell cultures. Mol Biol Cell [Suppl] 7:652a, 3791.

Calderón FH, von Bernhardi R, De Ferrari GV, Luza S, Aldunate R, Inestrosa NC (1998) Toxic effects of acetylcholinesterase on neuronal and glial-like cells in vitro. Mol Psychiatry, in press.

Campos EO, De Mello FG, Inestrosa NC (1997) Toxic effects of amyloid- $\beta$-peptide $(\mathrm{A} \beta)$, acetylcholinesterase (AChE) and $\mathrm{AChE}-\mathrm{A} \beta$ complex on cultured cells of avian retina. Paper presented at XI Meeting of the Chilean Cell Biology Society, Termas de Cauquenes, Chile, September.

Carson KA, Geula C, Mesulam M-M (1991) Electron microscopic localization of cholinesterase activity in Alzheimer brain. Brain Res 540:204-208.

Castaño EM, Prelli F, Pras M, Frangione B (1995) Apolipoprotein E carboxyl-terminal fragments are complexed to amyloid A and J. J Biol Chem 270:17610-17615.

Cras P, Kawai M, Lowery D, Gonzalez-DeWhitt P, Greenberg B, Perry G (1991) Senile plaque neurites in Alzheimer disease accumulate amyloid precursor protein. Proc Natl Acad Sci USA 88:7552-7556.

Dajas F, Bolioli B, Castello ME, Silveira R (1987) Rat striatal acetylcholinesterase inhibition by fasciculin (a polypeptide from green mamba snake venom). Neurosci Lett 77:87-91.

De Mello FG, Bachrach U, Nirenberg M (1976) Ornithine and glutamic acid decarboxylase activities in the developing chick retina. J Neurochem 27:847-851.

Dickson DW, Crystal HA, Mattiace LA, Masur DM, Blau AD, Davies P, Yen SH, Aronson MK (1991) Identification of normal and pathological aging in prospectively studied nondemented elderly humans. Neurobiol Aging 13:179-189.

Ellman GL, Courtney KD, Andres V, Featherstone RM (1961) A new rapid colorimetric determination of acetylcholinesterase activity. Biochem Pharmacol 7:88-95.

Enna SJ, Snyder SH (1976) Gamma-aminobutyric acid (GABA) receptor binding in mammalian retina. Brain Res 115:174-179.

Evans KC, Berger EP, Cho C-G, Weisgraber KL, Lansbury PT (1995) Apolipoprotein $\mathrm{E}$ is a kinetic but not a thermodynamic inhibitor of amyloid formation: implications for the pathogenesis and treatment of Alzheimer disease. Proc Natl Acad Sci USA 92:763-767.

Ferrone FA, Hofrichter J, Eaton WA (1985) Kinetics of sickle hemoglobin polymerization. II. A double nucleation mechanism. J Mol Biol 183:611-631.

Gentry MK, Moorad DR, Hur RS, Saxena A, Ashani Y, Doctor BP (1995) Characterization of monoclonal antibodies that inhibit the catalytic activity of acetylcholinesterases. J Neurochem 64:842-849.

Geula C, Mesulam M-M (1989) Special properties of cholinesterases in the cerebral cortex of Alzheimer's disease. Brain Res 498:185-189.

Geula C, Mesulam M-M (1994) Cholinergic systems and related neuropathological predilection patterns in Alzheimer disease. In: Alzheimer disease (Terry RD, Katzman R, Bick KL, eds), pp 263-291. New York: Raven.

Gómez-Ramos P, Mufson EJ, Morán MA (1992) Ultrastructural localization of acetylcholinesterase in neurofibrillary tangles, neuropil and senile plaques in aged and Alzheimer's brain. Brain Res 569:229-237.

Greene LA, Tischler AS (1976) Establishment of a noradrenergic clonal line of rat adrenal pheochromocytoma cells which respond to nerve growth factor. Proc Natl Acad Sci USA 73:2424-2428.

Harper JD, Lansbury Jr PT (1997) Models of amyloid seeding in Alzheimer's disease and scrapie: mechanistic truths and physiological consequences of the time-dependent solubility of amyloid proteins. Annu Rev Biochem 66:385-407.

Hensley K, Carrey JM, Mattson MP, Aksenova M, Harris M, Wu JF, Floyd RA, Butterfield DA (1994) A model for $\beta$-amyloid aggregation and neurotoxicity based on free radical generation by the peptide: relevance to Alzheimer's disease. Proc Natl Acad Sci USA 91:3270-3274.
Hobbiger F, Peck AW (1969) Hydrolysis of suxamethonium by different types of plasma. Br J Pharmacol 37:258-271.

Howllett DR, Jennings KH, Lee DC, Clarck MSG, Brown F, Wetzel R, Wood SJ, Camilleri D, Roberts GW (1995) Aggregation state and neurotoxic properties of Alzheimer $\beta$-amyloid peptide. Neurodegeneration 4:23-32.

Inestrosa NC, Perelman A (1989) Distribution and anchoring of molecular forms of acetylcholinesterase. Trends Pharmacol Sci 10:325-329.

Inestrosa NC, Perelman A (1990) Association of acetylcholinesterase with the cell surface. J Membr Biol 118:1-9.

Inestrosa NC, Reiness CG, Reichardt LF, Hall ZW (1981) Cellular localization of the molecular forms of acetylcholinesterase in rat pheochromocytoma PC12 cells treated with nerve growth factor. J Neurosci 1:1260-1267.

Inestrosa NC, Roberts WL, Marshall TL, Rosenberry TL (1987) Acetylcholinesterase from bovine caudate nucleus is attached to membranes by a novel subunit distinct from those of acetylcholinesterase in other tissues. J Biol Chem 262:4441-4444.

Inestrosa NC, Alvarez A, Calderon FH (1996a) Acetylcholinesterase is a senile plaque component that promotes assembly of $\beta$-peptide into Alzheimer's filaments. Mol Psychiatry 1:359-361.

Inestrosa NC, Alvarez A, Pérez CA, Moreno RD, Vicente M, Linker C, Casanueva OI, Soto C, Garrido J (1996b) Acetylcholinesterase accelerates assembly of amyloid- $\beta$-peptides into Alzheimer's fibrils: possible role of the peripheral site of the enzyme. Neuron 16:881-891.

Inestrosa NC, Alvarez A, Garrido J, Calderón F, Bronfman FC, Dajas F, Gentry MK, Doctor BP (1997) Acetylcholinesterase promotes Alzheimer's $\beta$-amyloid fibril formation. In: Alzheimer's disease: biology, diagnosis and therapeutics (Iqbal K, Winblad B, Nishimura T, Takeda M, Wisniewski HM, eds), pp 501-510. London: Wiley.

Jarrett JT, Berger EP, Lansbury Jr PT (1993) The carboxy-terminus of the $\beta$-amyloid protein is critical for the seeding of amyloid formation: implications for the pathogenesis of Alzheimer's disease. Biochemistry 32:4693-4697.

Kalaria RN, Kroon SN, Grahovac I, Perry G (1992) Acetylcholinesterase and its association with heparan sulphate proteoglycans in cortical amyloid deposits of Alzheimer's disease. Neuroscience 51:177-184.

Karlsson E, Mbugua P, Rodriguez-Ithurralde D (1984) Fasciculins, anticholinesterase toxins from the venom of the green mamba Dendroaspis angusticeps. J Physiol (Paris) 79:232-240.

Karnovsky MJ, Roots L (1964) A "direct-coloring" thiocholine method for cholinesterases. J Histochem Cytochem 12:219-221.

Kasa P, Rakonczay Z, Gulya K (1997) The cholinergic system in Alzheimer's disease. Prog Neurobiol 52:511-535.

Katzman R, Kawas CH (1994) The epidemiology of the dementia and Alzheimer disease. In: Alzheimer disease (Terry RD, Katzman R, Bick KL, eds), pp 105-122. New York: Raven.

Klunk WE, Pettegrew JW, Abraham DJ (1989) Two simple methods for quantifying low-affinity dye-substrate binding. J Histochem Cytochem 37:1293-1297.

Laemmli UK (1970) Cleavage of structural proteins during the assembly of the head of bacteriophage $\mathrm{T}_{4}$. Nature 227:680-685.

LeVine H (1993) Thioflavine T interaction with synthetic Alzheimer's disease $\beta$-amyloid peptides: detection of amyloid aggregation in solution. Protein Sci 2:404-410.

Lorenzo A, Yankner BL (1994) $\beta$-Amyloid neurotoxicity requires fibril formation and is inhibited by Congo red. Proc Natl Acad Sci USA 91:12243-12247.

Makman MH, Dvorkin B, Horowitz SG, Thal LJ (1980) Properties of dopamine agonist and antagonist binding sites in mammalian retina. Brain Res 194:403-418.

Mann DMA, Esiri MM (1989) The pattern of acquisition of plaques and tangles in the brains of patients under 50 years of age with Down's syndrome. J Neurol Sci 89:169-179.

Markwell MA (1982) A new solid-state reagent to iodinate proteins. I. Conditions for the efficient labeling of antiserum. Anal Biochem 125:427-432.

Massoulié J, Pezzementi L, Bon S, Krejci E, Vallette FM (1993) Molecular and cellular biology of cholinesterases. Prog Neurobiol 41:31-91.

Masters CL, Simms G, Weinman NA, Multhaup G, McDonald BL, Beyreuther K (1985) Amyloid plaque core protein in Alzheimer's disease and Down syndrome. Proc Natl Acad Sci USA 82:4245-4249.

Mattson MP, Cheng B, Davis D, Bryant K, Lieberburg I, Rydel R (1992) $\beta$-Amyloid peptides destabilize calcium homeostasis and render human cortical neurons vulnerable to excitoxicity. J Neurosci 12:376-389. 
Mesulam M-M, Geula C (1994) Butyrylcholinesterase reactivity differentiates the amyloid plaques of aging from those of dementia. Ann Neurol 36:722-724.

Mesulam M-M, Geula C, Morán A (1987) Anatomy of cholinesterase inhibition in Alzheimer's disease: effect of physostigmine and tetrahydroaminoacridine on plaques and tangles. Ann Neurol 22:683-691.

Mimori Y, Nakamura S, Yukawa M (1997) Abnormalities of acetylcholinesterase in Alzheimer's disease with special reference to effect of acetylcholinesterase inhibitors. Behav Brain Res 83:25-30.

Morán MA, Mufson EJ, Gómez-Ramos P (1993) Colocalization of cholinesterases with $\beta$-amyloid protein in aged and Alzheimer's brain. Acta Neuropathol (Berl) 85:362-369.

Mosmann T (1983) Rapid colorimetric assay for cellular growth and survival: application to proliferation and cytotoxicity assays. J Immunol Methods 65:55-63.

Naiki H, Higuchi K, Nakakuki K, Takeda T (1991) Kinetic analysis of amyloid fibril polymerization in vitro. Lab Invest 65:104-110.

Nakamura S, Kawashima S, Nakang S, Tsuji T, Araki W (1990) Subcellular distribution of acetylcholinesterase in Alzheimer's disease: abnormal localization and solubilization. J Neural Trans [Suppl] 30:13-23.

Namba Y, Tomonaga M, Kawaski H, Otomon E, Ikeda K (1991) Apolipoprotein E immunoreactivity in cerebral amyloid deposits and neurofibrillary tangles in Alzheimer's disease and kuru plaque amyloid in Creutzfeldt-Jacob disease. Brain Res 541:163-166.

Naslünd J, Thyberg J, Tjernberg LO, Wernstedt C, Karstrom AR, Bogdanovic N, Gandy SE, Lannfelt L, Terenius L, Nordstedt C (1995) Characterization of stable complexes involving apolipoprotein $\mathrm{E}$ and the amyloid $\beta$ peptide in Alzheimer's disease brain. Neuron 15:219-228.

Oda T, Wals P, Osterburg HH, Johnson SA, Pasinetti GM, Morgan TD, Rozovsky Y, Stine WB, Snyder SW, Holzman TF, Fratt GA, Finch CE (1995) Clusterin (ApoJ) alters the aggregation of amyloid $\beta$-peptide $\left(\mathrm{A} \beta_{1-42}\right)$ and forms slowly sedimenting $\mathrm{A} \beta$ complexes that cause oxidative stress. Exp Neurol 136:2-31.

Paes de Carvalho R, De Mello FG (1982) Adenosine-elicited accumulation of adenosine $3{ }^{\prime}, 5^{\prime}$-cyclic mono-phosphate in the chick embryo retina. J Neurochem 38:493-500.

Pike CJ, Burdick D, Walencewicz AJ, Glabe CG, Cotman CW (1993) Neurodegeneration induced by $\beta$-amyloid peptides in vitro: the role of peptide assembly state. J Neurosci 13:1676-1687.

Puro DG, De Mello FG, Nirenberg M (1977) Synapse turnover: the formation and termination of transient synapses. Proc Natl Acad Sci USA 74:4977-4981.

Puttfarcken PS, Manelli AM, Falduto MT, Godfrey SG, LaDu MJ (1997) Effect of apolipoprotein $\mathrm{E}$ on neurite outgrowth and $\beta$-amyloidinduced toxicity in developing rat primary hippocampal cultures. J Neurochem 68:760-769.

Radic Z, Reiner E, Taylor P (1991) Role of the peripheral anionic site on acetylcholinesterase: inhibition by substrates and coumarin derivatives. Mol Pharmacol 39:98-104.

Reyes AE, Perez DR, Alvarez A, Garrido J, Gentry MK, Doctor BP, Inestrosa NC (1997) A monoclonal antibody against acetylcholinesterase inhibits the formation of amyloid fibrils induced by the enzyme. Biochem Biophys Res Commun 232:652-655.

Rodriguez-Ithurralde D, Silveira R, Barbeito L, Dajas F (1983) Fasciculin a powerful anticholinesterase polypeptide from Dendroaspis angusticeps. Neurochem Int 5:267-274.

Roher A, Wolfe D, Palutke M, KuKuruga D (1986) Purification, ultrastructure, and chemical analysis of Alzheimer disease amyloid plaque core protein. Proc Natl Acad Sci USA 83:2662-2666.

Sayre LM, Zagorski MG, Surewicz WK, Krafft GA, Perry G (1997)
Mechanisms of neurotoxicity associated with amyloid $\beta$ deposition and the role of free radicals in the pathogenesis of Alzheimer's disease: a critical appraisal. Chem Res Toxicol 10:518-526.

Schagger H, von Jagow G (1987) Tricine-sodium dodecyl sulfatepolyacrylamide gel electrophoresis for the separation of proteins in the range from 1 to $100 \mathrm{kDa}$. Anal Biochem 166:368-379.

Schätz CR, Geula C, Mesulam M (1990) Competitive substrate inhibition in the histochemistry of cholinesterase activity in Alzheimer's disease. Neurosci Lett 117:56-61.

Selkoe DJ (1996) Amyloid $\beta$-protein and the genetics of Alzheimer's disease. J Biol Chem 271:18295-18298.

Selkoe DJ (1997) Alzheimer's disease: genotypes, phenotype, and treatments. Science 275:630-631.

Sheffield JB, Moscona AA (1970) Electron microscopic analysis of aggregation of embryonic cells: the structure and differentiation of aggregates of neural retina cells. Dev Biol 23:36-61.

Shen ZX (1994) Acetylcholinesterase provides deeper insights into Alzheimer's disease. Med Hypotheses 43:21-30.

Small DH, Michaelson S, Sberna G (1996) Non-classical actions of cholinesterases: role in cellular differentiation, tumorigenesis and Alzheimer's disease. Neurochem Int 28:453-483.

Snow AD, Mar H, Nochlin D, Kimata K, Kato M, Susuki S, Hassell J, Wight TN (1988) The presence of heparan sulfate proteoglycan in the neuritic plaques and congophilic angiopathy in Alzheimer's disease. Am J Pathol 133:456-463.

Solomon B, Koppel R, Frankel D, Hanan-Aharon E (1997) Disaggregation of Alzheimer $\beta$-amyloid by site-directed mAb. Proc Natl Acad Sci USA 94:4109-4112.

Soreghan B, Kosmoski J, Glabe C (1994) Surfactant properties of Alzheimer's $\mathrm{A} \beta$ peptides and the mechanism of amyloid aggregation. J Biol Chem 269:28551-28554.

Soto C, Brañes MC, Alvarez J, Inestrosa NC (1994) Structural determinants of the Alzheimer's amyloid $\beta$-peptide. J Neurochem 63:1191-1198.

Sugiyama H, Daniels MP, Nirenberg M (1977) Muscarinic acetylcholine receptors of the developing retina. Proc Natl Acad Sci USA 74:5524-5528.

Taylor P (1991) The cholinesterases. J Biol Chem 266:4025-4028.

Ulrich J, Meier-Ruge W, Probst A, Meier E, Ipsen S (1990) Senile plaques: staining for acetylcholinesterase and A4 protein. A comparative study in the hippocampus and entorhinal cortex. Acta Neuropathol (Berl) 80:624-628.

Van Leeuwen FW, de Kleijn DPV, van den Hurk HH, Neubauer A, Sonnemans MAF, Sluijs JA, Koycu S, Ramdjielal RDJ, Salehi A, Martens GJM, Grosveld FG, Burbach JPH, Hol EM (1998) Frameshift mutants of $\beta$ amyloid precursor protein and ubiquitin-B in Alzheimer's and down patients. Science 279:242-247.

Vogel Z, Nirenberg M (1976) Localization of acetylcholine receptors during synaptogenesis in retina. Proc Natl Acad Sci USA 73:1806-1810.

Vogel Z, Daniels MP, Nirenberg M (1976) Synapse and acetylcholine receptor synthesis by neurons dissociated from retina. Proc Natl Acad Sci USA 73:2370-2374.

Wright CI, Geula C, Mesulam M-M (1993) Protease inhibitors and indoleamines selectively inhibit cholinesterases in the histopathologic structures of Alzheimer disease. Proc Natl Acad Sci USA 90:683-686.

Yankner BA (1996) Mechanism of neuronal degeneration in Alzheimer's disease. Neuron 16:921-932.

Yankner BA, Dawes LR, Fisher S, Villa-Komaroff L, Oster-Granite ML, Neve RL (1989) Neurotoxicity of a fragment of the amyloid precursor associated with Alzheimer's disease. Science 245:417-420. 